\author{
NBER WORKING PAPER SERIES
}

\title{
BANKS AND DERIVATIVES
}

Gary Gorton

Richard Rosen

Working Paper No. 5100

\section{NATIONAL BUREAU OF ECONOMIC RESEARCH 1050 Massachusetts Avenue \\ Cambridge, MA 02138 \\ April 1995}

Thanks to Ben Bernanke, Peter Garber, Julio Rotemberg, Cathy Schrand, and especially Greg Duffee for comments and suggestions. This paper is part of NBER's research programs in Asset Pricing and Corporate Finance. Any opinions expressed are those of the authors and not those of the National Bureau of Economic Research.

(c) 1995 by Gary Gorton and Richard Rosen. All rights reserved. Short sections of ext, not to exceed two paragraphs, may be quoted without explicit permission provided that full credit, including $\odot$ notice, is given to the source. 


\title{
BANKS AND DERIVATIVES
}

\begin{abstract}
In the last ten to fifteen years financial derivative securities have become an important, and controversial, product for commercial banks. The controversy concerns whether the size, complexity, and risks associated with these securities, the difficulties with accurately reporting timely information concerning the value of firms' derivative positions, and the concentration of activity in a small number of firms, has substantially increased the risk of collapse of the world banking system. Despite the widespread attention to derivatives, there has been little systematic analysis. We estimate market values and interest-rate sensitivities of interest rate swap positions of U.S. commercial banks to empirically address the question of whether swap contracts have increased or decreased systematic risk in the U.S. banking system. We find that the banking system as a whole faces little net interest-rate risk from swap portfolios.
\end{abstract}

Gary Gorton

Department of Finance

The Wharton School

University of Pennsylvania

Philadelphia, PA 19104

and NBER
Richard Rosen

Department of Finance

The Wharton School

University of Pennsylvania

Philadelphia, PA 19104 


\section{Introduction}

In the last ten to fifteen years financial derivative securities have become an important, and controversial, product. ${ }^{1}$ These securities are powerful instruments for transferring and hedging risk. However, they also allow agents to quickly and cheaply take speculative risk. Determining whether agents are hedging or speculating is not a simple matter because it is difficult to value portfolios of derivatives. The relationship between risk and derivatives is especially important in banking since banks dominate most derivatives markets and, within banking, derivative holdings are concentrated at a few large banks. If large banks are using derivatives to increase risk, then recent losses on derivatives, such as those of Procter and Gamble, and Orange County, may seem small in comparison to the losses by banks. If, in addition, the major banks are all taking similar gambles, then the banking system is vulnerable. This paper is the first to estimate the market value and interest-rate sensitivity of bank derivative positions. We focus on a single important derivative security, interest rate swaps, and find evidence that the banks, as a whole, take the same side in interest rate swaps. The banking system's net position is somewhat interest-rate sensitive. Relatively small increases in interest rates can cause fairly large decline in the value of swaps held by banks. However, our evidence suggests that swap positions are largely hedged elsewhere in bank portfolios.

Derivative securities are contracts that derive their value from the level of an underlying interest rate, foreign exchange rate, or price. Derivatives include swaps, options, forwards, and futures. At the end of 1992 the notional amount of outstanding interest rate swaps was $\$ 6.0$ trillion and the outstanding notional amount of currency swaps was \$1.1 trillion (Swaps Monitor (1993)). U.S. commercial banks alone held \$2.1 trillion of interest rate swaps and \$279 billion of foreign exchange swaps (Call Reports of Income and Condition). Moreover, derivatives are concentrated in a relatively small number of financial intermediaries. For example, almost two-

\footnotetext{
' A large number of reports by government and trade organizations have been devoted to studying derivatives. See Bank for International Settlements (1992), Bank of England (1987, 1983), Basle Committee on Banking Supervision (1993A, B, C, D), Board of Governors of the Federal Reserve System, et. al. (1993), Commodity Futures Trading Commission (1993), Group of Thirty (1993A, B, 1994), House Banking Committee Minority Staff (1993), House Committee on Banking, Finance and Urban Affairs (1993), U.S. Comptroller of the Currency (1993A, B), and U.S. Government Accounting Office (1994).
} 
thirds of swaps are held by only twenty financial intermediaries. Of the amount held by U.S. commercial banks, seven large dealer banks account for over 75 percent.

An interest rate swap is a contract under which two parties exchange the net interest payments on an amount known as the "notional principal". In the simplest interest rate swap, at a series of six-month intervals, one party pays the current interest rate (such as the six-month LIBOR) on the notional principal while its counterparty pays a preset, or fixed, interest rate on the notional principal. The notional principal is never exchanged. By convention, interest rates in a swap are set so that the swap has a zero market value at initiation. If there are unanticipated changes in interest rates, the market value of a swap will change, becoming an asset for one party and a liability for the counterparty.

Valuing an interest rate swap requires information on when the swap was initiated (or what the fixed interest rate is), the terms of payment, and the remaining maturity of the swap. Firms are not required to reveal this information, and few firms reveal even market values for their swap portfolios. ${ }^{2}$ Moreover, it is not the current market value which is most important. The key factor in determining the risk of a swap portfolio is the interest-rate sensitivity of the portfolio. Swap value can be very volatile. If interest rates change slightly, the value of a swap can change dramatically. Thus, monitoring the risks from swaps is difficult. Partially in response to this, proposals for reforming swap reporting require institutions to reveal the interest-rate sensitivity of their swap positions (as well as sensitivities to other factors such as foreign exchange rates. Until institutions are required to report the interest-rate sensitivity of their swap portfolios, swaps are an easy way to quickly and inexpensively alter the risk of a portfolio. Because of insufficient current reporting requirements, swaps can be used to make it more difficult for outsiders to monitor risk.

Difficulty in monitoring risk is especially important when the party entering into a derivative transaction such as a swap is an agent managing money for outside principals. Whenever outside principals cannot fully monitor, an agent may find it optimal to speculate (Dow

${ }^{2}$ Starting in 1994, banks will be required to report for interest rate, foreign exchange, equity, and commodity derivatives, the value of contracts that are liabilities as well as the value of contracts that are assets. 
and Gorton (1994)). This means that recent reports of losses by Proctor and Gamble, Gibson Greetings, Metallgesellschaft, and Orange County may signal that agents, whether they are corporate treasurers or professional money managers, have been using derivatives to speculate. ${ }^{3}$ These kinds of losses have direct and indirect impacts. Principals and other stakeholders in an organization hit by losses obviously suffer. There is also a possible indirect effect through signalling. Since derivatives are opaque, a realized loss by one organization may be viewed as information about the portfolio positions of other organizations. These effects are the natural result of information release in an agency setting. They hold true for corporations, municipalities, fund managers, and banks. The problems from derivatives transactions thus come from information problems. This points out the need for changes in either accounting rules or investment regulations.

When banks use derivatives, the problems are more severe. There are two issues. First, even knowing more about the derivatives position of a bank may not allow outside stakeholders to determine the overall riskiness of the bank. Banks invest in many non-derivative instruments that are illiquid and opaque. Thus, even if the value of their derivative positions were known, it would be hard to know how subject to interest-rate and other risks the entire bank would be. This makes them different from most other organizations that invest in derivatives.

Second, bank failures can have external effects. The failure of several large banks can lead to the breakdown of the payments system and the collapse of credit markets for firms. These problems, known collectively as "systemic risk," are of concern if large banks all take similar positions in derivatives markets or are perceived as taking similar positions. It is clear that if banks have similar positions, the failure of one bank may mean the failure of many. Because derivatives are opaque, even if banks have different positions, outside principals may not be able to determine whether the failure of one bank signals trouble at other banks.

Systemic risk issues lead us to examine banks. We further focus on interest rate swaps because interest-rate risk is nondiversifiable and because banks naturally are repositories of

\footnotetext{
${ }^{3}$ The agents in these example have all claimed that any "speculative" risk they were taking in their derivative positions was unintentional.
} 
interest-rate risk. Banks bear interest-rate risk if their assets reprice at different frequencies than their liabilities. Banks may be using interest rate swaps to hedge -- that is, to reduce interest-rate risk -- or to speculate. ${ }^{4}$

To estimate interest-rate sensitivity, the first step in determining whether there is systemic risk, we need to put more structure on the existing data. The only available data comes from the Call Reports of Income and Condition where banks report notional values, a number called "replacement cost," and the remaining maturity of interest rate derivatives (more than one year remaining and less than one year remaining). The replacement cost of a bank's interest rate derivatives is the value of the derivatives that are assets to the bank (not netting out derivatives that are liabilities). These data are insufficient to calculate interest-rate sensitivity, or even market value. We make simple assumptions that allow us to go from the available data to estimates of market value and interest-rate sensitivity.

Our estimates of interest-rate sensitivity show that the banking system has a net swap position that falls in value if interest rates rise. This sensitivity is due to the positions of large banks. Small banks tend to have only minor exposure to interest rates in their swap positions. While our estimates show that large banks have interest-rate sensitive swap positions, this does not mean that the banks' equity positions are interest-rate-sensitive to the same extent. The banks may use swaps to hedge on-balance sheet interest-rate risk or they could use other derivatives markets, such as the futures market, to hedge their swap exposure. We investigate whether swap exposure is hedged elsewhere on bank balance sheets. We find that large banks have mostly hedged swap interest-rate risk. This leaves open the very important question of who is acquiring the interest-rate risk from large banks.

The paper proceeds as follows. In Section II we provide some background on interest rate swaps. In Section III, the role of banks in the swap market is discussed. We discuss several hypotheses about bank involvement in the swap market. Section IV presents the model that allows us to derive market value and interest-rate sensitivity from published data. Section V

\footnotetext{
${ }^{4}$ Note that the same questions arise in foreign currency derivatives, but, unlike with interest rate derivatives, there is no easy way to know from a bank's currency derivatives position whether it is hedging or speculating.
} 
outlines the procedure for calibrating the model. Estimates of market value and interest-rate sensitivity are given in Section VI. Section VII addresses the question of whether banks hedge their swap exposure. Conclusions are presented in Section VIII.

\section{Interest Rate Swaps: Background}

\section{A) Definition of an Interest Rate Swap}

An interest rate swap is a contract under which two parties agree to pay each other's interest obligations. The cash flows in a swap are based on a "notional" principal which is used to calculate the cash flow (but is not exchanged). The two parties are known as "counterparties." Usually, one of the counterparties is a financial intermediary. At a series of stipulated dates, one party (the fixed-rate payer) owes a "coupon" payment determined by the fixed interest rate set at contract origination, $\mathrm{r}_{\mathrm{N}}$, and, in return, is owed a "coupon" payment based on the relevant floating rate, $r_{t}$. For most swap contracts, LIBOR is used as the floating rate while the fixed rate is set to make the swap have an initial value of zero. ${ }^{3}$ The fixed rate can be thought of as a spread over the appropriate-maturity Treasury bond, where the spread can reflect credit risk. So, for example, a five-year swap might set the fixed rate at the five-year Treasury bond rate plus 25 basis points and the floating rate at the six-month LIBOR.

When the swap is entered into, the fixed rate is set at $\mathrm{r}_{\mathrm{N}}$, where $\mathrm{N}$ is the origination date of the swap. The fixed-rate payer pays: $r_{N} L$, where $L$ is the notional principal. The fixed-rate payer receives: $r_{t} L$, where $r_{t}$ is the interest rate at the last reset date. Notice that the notional principal is never exchanged. At each settlement date $t$, only the difference in the promised interest payments is exchanged. So, the fixed-rate payer receives (or pays) a difference check: $\left(r_{t}-r_{N}\right) L$.

A swap is a zero-sum transaction. While the initial value of a swap is zero, over the life of the swap interest rates may change causing the swap to become an asset to one party (the fixedrate payer if rates rise) or a liability (for the fixed-rate payer if rates fall); clearly one party's gain

\footnotetext{
${ }^{5}$ The floating rate typically is reset every six months using the then current six-month rate. Since the floating rate is determined six months prior to settlement, throughout the swap the cash flow at the next settlement date is known six months in advance.
} 
is the other's loss. For example, if the floating rate rises from $r_{t}$ to $r_{t}{ }^{\prime}$, then the difference check received by the fixed-rate payer rises from $\left(r_{l}-r_{N}\right) L$ to $\left(r_{l}{ }^{\prime}-r_{N}\right) L$.

Figure 1 provides examples of a swap. We define a swap participant as "long" if the participant pays a fixed rate and receives a floating rate. The top panel shows a bank with a long position. The bank pays $7.15 \%$ to its counterparty and receives the six-month LIBOR rate. So, if the notional principal is $\$ 1$ million and payments are made every six months, then when LIBOR is $6.5 \%$, the bank pays a net of $\$ 3,250$ to its counterparty ( $\$ 1$ million $*(7.15 \%-6.5 \%) / 2)$. When LIBOR is $7.5 \%$, on the other hand, the bank receives $\$ 1,750$. Thus, the bank gains when interest rates rise.

The middle panel shows the bank in a short position. Notice that we have implicitly assumed that the bank is a dealer, since the fixed rate it pays is 10 basis points less than the fixed rate it receives. This 10 basis point difference is the dealer fee. When a bank has a short position, it loses if interest rates rise.

The last panel of Figure 1 shows the bank making both "legs" of a swap. The bank's position is hedged, since no matter how interest rates move, the bank receives a net of 10 basis points from the swap (assuming no default).

\section{B) Risks in Swaps}

The major risks from swaps include those that are common to all fixed-income securities. Interest-rate risk exists because changes in interest rates affect the value of a swap. Also, credit risk exists because a counterparty may default. If a swap is a liability, then default by a counterparty is not costly. Also, notional principal is not exchanged in a swap, so the magnitude of credit risk is reduced.

To examine interest-rate risk, we need to be able to value swaps as a function of interest rates. To do this we can view a swap as a combination of loans. The fixed-rate payer can be viewed as borrowing at a fixed rate and simultaneously lending the same amount at a floating rate. For example, from the point of view of the fixed-rate payer, a five-year swap is equivalent to issuing a five-year coupon bond and buying a five-year floating-rate obligation (where the floating 
rate is set such that the initial value of the exchange is zero). This helps us to value swaps subsequent to their issue. For example, looking forward two years into the five-year swap, the fixed-rate payer will have, in effect, issued a three-year coupon bond at the original five-year rate and will have bought a three-year floating-rate bond. At that point in time, the market value of the swap to the fixed-rate payer is the difference between the value of a three-year bond issued then and the value of the initial five-year bond with three years left to maturity.

To value a swap, let $\omega$ be the original maturity of the swap, $\mathrm{N}$ be the date of origination, and $t$ be the date at which we are valuing the swap. Further, let the value at date $t$ of a one dollar (of principal) bond (i.e., $L=1$ ) issued at $N$ with original maturity $\omega$ be: $\Gamma_{L, N}{ }^{\circ}$. Notice that a floating-rate bond is always priced at par (ignoring the lagged reset). This allows us to represent the value of a swap with $\$ 1.00$ of notional principal as:

$$
P_{L, \mathbb{N}}{ }^{\omega}=\left[1-\Gamma_{L, N}{ }^{\infty}\right] .
$$

Now it is straightforward to see how the value of a swap changes when interest rates change. As interest rates move, the value of the bond, $\Gamma$, changes and the swap value is altered accordingly. Describing the change in interest rates is, however, more complicated since it requires a model of the term structure of interest rates.

To this point we have ignored default. The effect of default to the holder of a swap depends on whether the swap is an asset or a liability at the time of default. If a counterparty defaults but the swap is a liability to the holder (i.e., the holder is making payments to the counterparty), then the holder continues to make payments and there is no immediate effect. If the swap is an asset, however, then default means that the counterparty should be making payments, but does not. The loss to the holder is equivalent to the value of the swap at that point. The replacement cost of a swap is the loss that would be incurred if the counterparty defaulted. Note that replacement cost is always nonnegative since default by an asset-holder implies a zero loss to its counterparty. 


\section{Banks and Interest Rate Swaps}

\section{A) Swap Positions of Banks}

Table 1 presents a list of the top swap firms listed by notional value of interest rate swap positions. Most of these firms are commercial banks. Five of the top ten firms by notional value are U.S. commercial banks, three are French state-owned banks, one is a British bank, and one is a U.S. securities firm. Moreover, eighteen of the top twenty firms with the largest swap positions are banks. These firms also tend to have large positions in other derivatives markets.

Within the U.S. banking system, swaps are concentrated in a few large banks. Table 2 shows the interest rate swap position of U.S. commercial banks in the last decade. Panel A, covering all commercial banks, shows that fewer than three percent of banks have any swaps at all. Furthermore, although roughly 200 banks hold swaps, over seventy-five percent of swap notional value is held by seven dealer banks (Panel B), and over ninety percent is held by thirty banks (Panels B and C). ${ }^{6}$

In the empirical work that follows, we restrict attention to banking organizations with total assets greater than $\$ 500$ million. Banks smaller than this generally do not use swaps, and account for an insignificant portion of the market. Except for the very largest banks, even banks larger than $\$ 500$ million in assets rarely hold significant amounts of swap notional value (see Panels D - F of Table 2). Panels D - F show that swaps account for a tiny fraction of total assets at banks below the top thirty.

Table 2 also shows that the potential risk to the banking system from swaps is much greater now than in the past because of the growth in bank swap positions. Over the period 1985-1993 swap holdings increased by 40 percent per year. The final two columns of Panel A show that the growth in swap notional value dwarfs the growth in assets and equity in the banking system. By the end of 1993 swap notional value was over ten times the total equity in the banking system.

\footnotetext{
${ }^{6}$ Dealer banks include BankAmerica, Bankers Trust, Chase Manhattan, Chemical Bank, Citicorp, First National Bank of Chicago, and JP Morgan.
} 
The concentration of swap holdings at a small number of banks is not necessarily a sign that swaps increase risk in the banking system. Swaps may allow interest rate to be transferred between banks in such a way that overall bank failure risk is reduced. Below, we show how banks can manage risk using swaps. Swap positions may be hedged in other derivatives markets or swaps may be held to hedge on-balance sheet positions. Another is that the concentration of swap holdings has to do with incentives for large banks to engage in risky activities. If this is the case, then swaps increase systemic risk.

\section{B) Bank Loans and Swaps}

We explore two hypotheses about why a few banks dominate the swaps market. One possibility is that banks in general dominate the swaps market because they face interest-rate risk as a byproduct of their business. Swaps can be used to manage this risk. The concentration among a few banks may occur because these banks specialize in managing the interest-rate risk for the entire banking system, which they may hedge in other markets. Another possibility is that regulatory distortions create an incentive for large banks to absorb interest risk from other banks and from nonbank firms, risk which the large banks do not hedge.

Traditionally, banks issued fixed-rate loans because borrowers wanted certainty of payment. $^{7}$ A fixed-rate loan involves two risks to the bank. First, the borrower may default (credit risk). Second, bank portfolios contain these loans plus primarily floating-rate (short-term) liabilities. Thus, if interest rates change after a loan contract has been signed, the value of the portfolio changes (interest-rate risk). By holding fixed-rate loans and floating-rate liabilities, the bank bears both credit risk and interest-rate risk.

Swaps allow the credit risk and interest-rate risk to be priced, traded, and held separately. Banks can use swaps to separate credit risk and interest-rate risk in two ways. Either a bank can issue a floating-rate loan to a borrower who then swaps to fixed with a third party (possibly another bank). In this case, the bank is left with floating-rate loans and floating-rate liabilities.

\footnotetext{
${ }^{7}$ Over the period 1977 - 1993, approximately forty percent (by value) of commercial loans were floating rate (Quarterly Terms of Banking Lending survey, Federal Reserve Board). There are no significant trends in the relative use of floating-rate loans over this period, overall or among banks of different sizes.
} 
Or, the bank can issue a fixed-rate loan and enter into a pay-fixed, receive-floating swap with a third party, possibly another bank. Again, the bank ends up effectively receiving a floating rate on its loans. Notice that in both cases, the third party is entering into a swap which receives fixed and pays floating. One of the issues we discuss below is whether large banks are the third parties in these swap transactions.

Swaps might allow interest-rate risk to be redistributed among banks, without changing the level of interest-rate risk in banking. Borrowers might borrow from one set of banks at floating rates but swap with large banks to hedge interest-rate risk. Essentially the same result occurs if borrowers take fixed-rate loans and then these smaller lenders swap with large banks to hedge the small banks' interest-rate risk. With either of these examples, large banks end up holding unhedged swap positions. This would leave overall risk in the system unchanged, but more highly concentrated.

The interest-rate risk at large banks depends on whether they hedge the risk transferred from the rest of the banking system, and whether they choose to absorb additional interest-rate risk (by speculating). The incentives for large banks to hedge interest-rate risk may be affected by the regulatory system. Roughly coinciding with the existence of the swaps market, large U.S. commercial banks have been (formally or informally) protected by the policy known as "too big to fail." Under this policy regulators extended deposit insurance at these banks to cover all liabilityholders, large or small. This serves as a subsidy to risk-taking by too-big-to-fail banks. This would suggest that big banks, but not small banks, would hold large, unhedged interest rate swap positions. To address this issue, we need to know not just the notional positions of banks, but whether the big banks that dominate the market have net long or net short swap portfolios, and whether they have hedged.

\section{Modelling the Market Value of Swaps}

In this section we discuss the available data and outline our empirical procedure for calculating the market values and interest-rate sensitivities of bank interest rate swap positions. 
A) Data

The data commercial banks are required to report to regulators is insufficient to derive either market values or interest-rate sensitivities without imposing some assumptions. There are three big problems with the data. First, banks do not report market values; instead they report only notional value, something called "replacement cost," and the fraction of interest rate derivatives with a remaining maturity of less than one year. Second, notional value is reported separately for interest rate swaps and other interest-rate based derivatives, but replacement cost and remaining maturity are reported only for the aggregate of all interest rate derivatives with credit risk, including swaps, forwards, and options (but excluding futures). Finally, while banks were required to report notional value starting in the second quarter of 1985 , they were not required to report replacement cost and remaining maturity until the first quarter of 1990 . Thus, we have only four years of quarterly observations on replacement cost.

We have defined notional value above. Replacement cost, according to the Call Report instructions to banks, is as follows:

... the replacement cost [is] the mark-to-market value, for only those interest rate and foreign exchange rate contracts with a positive replacement cost ... not those contracts with negative mark-to-market values. The replacement cost is defined as the loss that would be incurred in the even of counterparty default, as measured by the net cost of replacing the contract at current market rates.

Replacement cost includes only the value of those contracts which because of interest rate movements have become assets. In other words, as we illustrate below, the market value of the bank's net position may be negative at the same time as replacement cost is positive. This fact does not seem widely understood. ${ }^{8}$

Table 3 presents data on notional values, replacement cost, and remaining maturity quarterly from 1990-1993. Over this period, notional value has more than doubled. Notice that the relationship between notional value and replacement value is not constant. Between the first

\footnotetext{
${ }^{8}$ Another issue with reported replacement cost concerns whether the number represents the positive value due to favorable interest rate movements or whether it also incorporates reductions in the credit risk of counterparties. In other words, at the root of the replacement cost number there is, presumably, a model which the bank uses to value its interest rate derivatives. Nothing is known about these models. Banks are not required to report their models, so we have no information about how credit risk enters into reported replacement cost.
} 
quarter of 1990 and the fourth quarter of 1991 , notional value rose $21 \%$ while replacement value doubled. From the fourth quarter of 1991 through the final quarter of 1993, notional value rose $68 \%$ while replacement cost rose by $49 \%$. The third column shows the proportion of interest rate derivatives with a remaining maturity of less than one year. Note that the ratio is constant over our sample period. The fourth column shows an estimated ratio for swaps alone. We discuss the derivation of these data later. The relationship among notional value, replacement cost, and maturity structure depends on interest rates. The effect of a rate movement on replacement value is influenced by both notional value and the maturity structure of swaps. The final column of Table 3 shows that interest rates declined through mid-1992, and then rose a small amount during the rest of our sample period. We return to this issue later.

\section{B) Replacement Cost and Market Value}

The relationship between replacement cost, which banks provide, and market value, which we want, depends on the maturity structure of swaps and the path of interest rates. We provide some examples to show that it not possible to infer market value in a straightforward way from changes in replacement cost.

By convention we assume that a long interest rate swap contract pays a fixed interest rate and receives a floating interest rate. Let:

$\mathrm{L}_{\mathrm{B}, \mathrm{N}}{ }^{\infty}$ be the dollar amount of long interest rate swap contracts at date $\mathrm{t}$ which were originated at date $\mathrm{N}$ with original maturity of $\omega$, and

$\mathrm{S}_{\mathrm{t}, \mathrm{N}}{ }^{\omega}$ be the dollar amount of short interest rate swap contracts at date $\mathrm{t}$ which were originated at date $\mathrm{N}$ with original maturity of $\omega$.

Banks report notional value and replacement cost. With the above notation, the notional value of a swap portfolio at time $t$ is given by: 


$$
N V_{t} \equiv \Sigma_{\infty} \sum_{N>t-\infty}\left[L_{i, N}^{\infty}+S_{t, N}^{\infty}\right]
$$

Replacement cost is given by:

$$
R C_{t}=\sum_{\infty} \sum_{N>t-\infty} \operatorname{Max}\left[L_{t N}^{\infty} P_{t N}^{\omega},-S_{t N}^{\omega} P_{t N}^{\omega}\right]
$$

where $P_{L, N}{ }^{\omega}$ is the value of a $\$ 1.00$ notional value swap to the fixed-rate payer written at date $\mathrm{N}$ with original maturity $\omega$. To understand (2) consider what happens to the value of a swap when interest rates change. If rates rise, then the swap becomes an asset to the fixed-rate payer and a liability to the floating-rate payer. Thus, the value of the swap is included in the "replacement cost" for the fixed-rate payer, but not for the floating-rate payer. On the other hand, if interest rates fall after a swap is made, then the value of the swap is included in "replacement cost" only for the floating-rate payer. The replacement cost of a portfolio is the sum of: (i) the values of contracts that pay a fixed rate and have a positive value, $P_{L, N}{ }^{\omega}>0$; and (ii) the values of contracts that pay a floating rate and have a positive value, $P_{L, N}{ }^{\omega}<0$.

The market value of a portfolio of swap contracts is:

$$
M V_{t} \equiv \sum_{\omega} \sum_{N>t-\omega}\left(L_{t, N}^{\omega}-S_{\iota, N}^{\omega}\right) P_{\iota, N}^{\omega}
$$

Comparing this equation to (2), notice that market value is the sum of all swap contracts, assets as well as liabilities. Replacement cost ignores liabilities.

To examine the relationship between replacement cost and market value, consider an example. Suppose there are three swaps outstanding in a portfolio, all with one year remaining. Table 4 gives the contract specifications for the swap portfolio. Assume that the floating rate is 6\% (Panel A of Table 4). Market value is:

$$
\begin{aligned}
M V_{\mathfrak{l}} & =\$ 3 \text { million }(-0.009)-\$ 1 \text { million }(0.009)-\$ 1 \text { million }(-0.0019) \\
& =-\$ 18,868
\end{aligned}
$$

Replacement cost is: 


$$
\mathrm{RC}_{\mathrm{t}}=-\$ 1 \text { million }(-0.0019)=\$ 18,868
$$

since only the last contract is an asset to the bank. So, market value is negative while replacement cost (as always) is positive.

If the floating rate changes to $5 \%$ from $6 \%$, then both the market value and the replacement cost are different (see Panel B of Table 4). In this case:

$$
\begin{aligned}
\mathbf{M V}_{\mathbf{t}} & =\$ 3 \text { million }(-0.019)-\$ 1 \text { million }(0)-\$ 1 \text { million }(-0.0029) \\
& =-\$ 28,571
\end{aligned}
$$

and

$$
\mathrm{RC}_{\mathrm{t}}=-\$ 1 \text { million }(-0.0029)=\$ 28,571
$$

so market value is lower than in the previous example, but replacement cost is higher!

Finally, notice that if the long contract in Table 4 has notional value of $\$ 1$ million rather than $\$ 3$ million, market value and replacement cost both increase when the interest rate falls from $6 \%$ to $5 \%$ : When the rate is $6 \%, \mathrm{MV}_{\mathrm{t}}=0$ and $\mathrm{RC}_{\mathrm{t}}=\$ 18,868$, while when the rate is $5 \%$, $M V_{t}=\$ 9,524$ and $R_{t}=\$ 28,571$. These examples illustrate that there is no systematic relationship between market value and replacement cost.

\section{C) Modeling Market Value}

We now present a minimal set of assumptions that lead to a relationship between replacement cost and market value. We use the fact that when interest rates change, both replacement cost and market value change. Without further structure, we have seen that we cannot infer the market value change from the change in interest rates. Under the assumptions that (i) the maturity structure of the contracts written is constant and (ii) that the direction (long or short) of new contracts written is also constant, we can derive market values from replacement cost and notional values. Notice that these assumptions are weaker than assuming that we know the direction (long or short) of new contracts written, since we only assume that the direction is constant over time. 
To understand the assumptions, we need some definitions. Let $\mathrm{f}_{\mathrm{N}}{ }^{\omega}$ be the fraction of new contracts written period in $\mathrm{N}$ that are of maturity $\omega\left(\right.$ so, $\left.\Sigma_{\omega} \mathrm{f}_{\mathrm{N}}^{\omega}=1\right)$. We also want the proportion of new contracts that are long and short. To do this, first define the notional value of new contracts originated at date $\mathrm{N}, \mathrm{NC}_{\mathrm{N}}$ :

$$
N C_{N}=\Sigma_{\infty}\left[L_{N, N}^{\omega}+S_{N, N}^{\omega}\right]
$$

Then, the shares of new contracts in existence at $t$ that were written at date $\mathrm{N}$ with original maturity $\omega$ that are, respectively, long and short are:

$$
l_{L N}^{\infty} \equiv \frac{L_{L N}^{\omega}}{f_{N}^{\infty} N C_{N}}
$$

and

$$
s_{t N}^{\infty} \equiv \frac{S_{L N}^{\infty}}{f_{N}^{\omega} N C_{N}}
$$

Note that this implies that:

$$
l_{N, N}^{\infty}+s_{N, N}^{\infty}=1
$$

We assume the following:

Assumption 1: For any maturity $\omega$ and issuance date $\mathrm{N}, \mathrm{f}_{\mathrm{N}}{ }^{\omega}=\mathrm{f}^{\omega}$.

Assumption 1 says that the proportion of contracts written that are of a given maturity is fixed over time. This assumption also says that the proportion of contracts that are written of a given maturity is the same over time regardless of whether the contract is long or short.

Assumption 2: For any $\omega, \mathrm{N}$, and $\mathrm{K}<\mathrm{N}$ : 


$$
l_{N}^{\infty}=l_{N-K}^{\infty}\left(\equiv l^{\infty}\right)
$$

Or, alternatively stated:

$$
\frac{L_{L N}^{\infty}}{f^{\omega} N C_{N}}=\frac{L_{L N-K}^{\infty}}{f^{\omega} N C_{N-K}}
$$

Assumption 2 says that the fraction of newly written long contracts with maturity $\omega$ is constant through time. (Assumption 1 said that the sum of long and short contracts of a given maturity written at any time is a constant fraction of the total contracts written at that time.)

Assumption 1 allows us to derive new contracts from notional value. Write notional value as:

$$
N V_{1}=\sum_{\infty} \sum_{N>t-\omega} f^{\omega} N C_{N}
$$

Equation (8) says that notional value is the sum of all contracts written in the past (i.e., at dates $\mathrm{N}$ ) that have not reached maturity (i.e., $N>t-\omega$ ). Given notional value and the $\mathrm{f}^{\omega}$, the system of equations in (8) has one equation and one unknown for each period. Solving this system of equations gives new contracts, which we use below.

To write replacement cost, we need to divide previously written contracts into assets and liabilities. Let $\left\{a_{\omega}\right\}$ be the set of dates such that contracts written on that date of maturity $\omega$ are assets at date $t$, i.e., $P_{L, N}{ }^{\omega} \geq 0$. Similarly, let $\left\{b_{\omega}\right\}$ be the set of dates such that contracts written on that date of maturity $\omega$ are liabilities at date $t$, i.e., $P_{b, N}{ }^{\circ}<0$. Now, rewrite replacement cost as:

$$
R C_{t}=\Sigma_{\omega} \Sigma_{a \in a \omega\}} L_{t, a}^{\omega} P_{t, a}^{\omega}-\Sigma_{\omega} \Sigma_{b \in\{b \omega\}} S_{t, b}^{\omega} P_{t, b}^{\omega}
$$

From Assumption 1 we know that: 


$$
f^{\infty} N C_{N}=L_{4 N}^{\omega}+S_{4 N}^{\infty}
$$

Substitute this into $\mathrm{RC}_{\mathrm{t}}$ :

$$
R C_{t}=\Sigma_{\infty} \sum_{a \in\{a,\}} L_{t a}^{\infty} P_{b a}^{\infty}-\sum_{a} \sum_{b \in\{b \omega\}}\left[f^{\omega} N C_{b}-L_{t b}^{\infty}\right] P_{t b}^{\omega}
$$

Or, rewriting:

$$
R C_{t}=\sum_{\omega} \sum_{N>t-\omega} L_{t, N}^{\infty} P_{t N}^{\omega}-\sum_{\omega} \sum_{b \in\{b \omega\}} f^{\alpha} N C_{N} P_{t b}^{\omega}
$$

Using Assumption 2, replacement cost can be written:

$$
R C_{t}=\Sigma_{\infty} \sum_{N>t-\infty} l^{\omega} f^{\infty} N C_{N} P_{\lfloor, N}^{\infty}-\sum_{\infty} \sum_{b \in\{b a\}} f^{\infty} N C_{b} P_{t b}^{\infty}
$$

To estimate the $\mathrm{l}^{\omega}$, we rewrite (12). Since the $\mathrm{l}^{\omega}$ only appear in the first set of summations, bring the terms in (12) that do not depend on $1^{\omega}$ together:

$$
R C_{t}+\sum_{\infty} \sum_{b \in\{b \omega\}} f^{\omega} N C_{b} P_{t b}^{\omega}=\Sigma_{\omega} \Sigma_{N>t-\infty} l^{\omega} f^{\omega} N C_{N} P_{t N}^{\omega}
$$

Now, define $\mathrm{RC}^{*}$ t to be the left-hand side of (13):

$$
R C_{t}^{*}=R C_{t}+\sum_{\omega} \sum_{b \in\{b \omega\}} f^{\alpha} N C_{b} P_{t b}^{a}
$$

and define $A^{\omega}{ }_{t}$ to be the known or assumed variables on the right-hand side of (13):

$$
A_{i}^{\infty} \equiv \Sigma_{N>t-\infty} f^{\infty} N C_{N} P_{t N}^{\infty}
$$

Then:

$$
R C_{\imath}^{*}=\Sigma_{\omega} A_{\imath}^{a} l^{\infty}
$$

which is the equation we use to find long and short swap positions. 
The variables in equation (15) are new contracts, which we find using (8); $f^{\circ}$, the maturity structure of new contracts; and bond prices. So, we can calculate $A_{t}^{\omega}$, which feeds in as a variable in (16). The same information determines $\mathrm{RC}_{\mathrm{t}}$ from (14). Using this, (16) can be solved for the $1^{\omega}$. Plugging the $l^{\omega}$ into (3) using the identity $l^{\omega}+s^{\omega}=1$ gives market value:

$$
M V_{t}=\sum_{\omega} \sum_{N>t-\infty}\left(r^{\omega}-s^{\omega}\right) f^{\omega} N C_{N} P_{t N}^{\omega}
$$

We are also interested in the interest-rate sensitivity of swap positions. We adopt a simple definition of interest-rate sensitivity by assuming that interest-rate sensitivity is the change in market value from a parallel shift in the yield curve (i.e., a one-factor term structure model):

$$
\frac{d M V_{t}}{d r_{t}}=\sum_{\infty} \Sigma_{N>t-\infty}\left(l^{\infty}-s^{\omega}\right) f^{\omega} N C_{N} \frac{d P_{t N}^{\omega}}{d r_{t}}
$$

The change in the price of the swap depends on how a coupon bond changes price when interest rates change. This is straightforward to compute. The simplification of a parallel shift in the yield curve is a common one.

\section{The Empirical Procedure for Finding Market Values}

\section{A) Calibration Procedure}

We find market values and interest-rate sensitivities by calibrating the model above using available data. To calculate market values and interest-rate sensitivities, we need:

(i) $R C_{t}$, replacement cost,

(ii) $P_{L N}^{\omega}$, prices for swaps of different maturities and origination dates,

(iii) $f^{\infty}$, the fraction of new contracts written by maturity, and

(iv) $N C_{N}$, new contracts written in each period.

We have data on replacement cost and prices. The missing piece in the puzzle is the fraction of new contracts written, the $f$ 's. Given $f$ 's, we can find new contracts using data on notional value. 
Since there are no data on the maturity structure of new contracts, we use indirect means to find the appropriate maturity structure.

We assume that initial swap maturities are between zero and five years. ${ }^{9}$ Divide swaps into five buckets by initial maturity: 0-1 year $\left(\mathrm{f}^{0}\right), 1-2$ years $\left(\mathrm{f}^{\mathrm{d}}\right), 2-3$ years $\left(\mathrm{f}^{2}\right), 3-4$ years $\left(\mathrm{f}^{3}\right)$, and 4-5 years $\left(f^{4}\right)$. We determine the $f$ 's by calibration using the one piece of information on maturity structure that banks report. Since 1990 banks have been required to report the notional value of interest rate derivatives (excluding futures) with remaining maturities of less than one year and greater than one year. Our strategy is to calibrate the maturity structure of new contracts so that the implied remaining maturities match the reported remaining maturities. Under Assumption 1, the maturity structure of swap contracts is assumed to be constant over time.

The calibration procedure leads us to heavily weight the $0-1$ year maturity bucket in order to match the reported data on remaining maturity. It is not surprising that banks have a lot of short-term swaps, since banks are not required to hold capital against swaps with a remaining maturity less than one year, but are required to hold capital against longer-term swaps.

Given assumptions on maturity structure, we calculate new contracts using (8). We have quarterly data on notional value from the second quarter of 1985 through the fourth quarter of 1993. While we only have replacement cost data starting in 1990, we calculate new contracts from 1985. A contract of five years written in the second quarter of 1985 will have a remaining maturity of one quarter in the first quarter of 1990. Thus, our new contracts data match our desire to allow for maturities at least as long as five years.

With our estimates of new contracts, we can use (16) to determine long positions. In (16), we determine five variables, $1^{0}, 1^{1}, 1^{2}, 1^{3}$, and $l^{4}$. These correspond to the fractions of contracts in each maturity bucket that are long, so each of the $1^{\omega}$ must be between 0 and 1 (see (5)). To impose these constraints when we calibrate, we use quadratic programming (see Hadley [1964]). Finally, given the $\mathrm{l}^{\omega}$, we can derive market value from (17) and interest-rate sensitivity from (18).

\footnotetext{
${ }^{9}$ To the extent that swaps have initial maturities of greater than five years, we underestimate the interest-rate sensitivity of banks' swap portfolios.
} 


\section{B) Preliminary Data Adjustments}

Replacement cost and the remaining maturity data, as mentioned above, are reported for all interest rate derivatives (excluding futures), while we are interested in swaps only. To get the replacement cost of swaps, we need to adjust the reported number to account for the replacement cost of non-swap interest rate derivatives. To determine how to adjust the data, we examined the annual reports of approximately the top 100 bank holding companies. Table 5 presents data from the annual reports of the U.S. banks with large swap holdings listed in Table 1, plus several other large banks with significant swap positions. The table shows the data on swaps from bank annual reports: notional value, replacement cost, and the ratio of replacement cost to notional value. Notice that, even in this group, only about half the banks report replacement cost (and fewer report market value). ${ }^{10}$ Among the banks that report replacement cost, the ratio of replacement cost to notional value varies across banks (and over time, though this is not shown in the table). As a comparison, we present data on the ratio of replacement cost to notional value for all nonswap interest rate derivatives. We get this last series of data by subtracting the annual report notional values and replacement costs for swaps from the same data for interest rate derivatives reported in the Call Reports. The table shows that the ratio is generally higher for swaps than for other interest rate derivatives. This is expected since the "other" category includes options, which have a lower interest-rate sensitivity.

Table 5 suggests that the swap ratio is equal to or higher than the ratio for non-swap interest rate derivatives. Since we rely on Call Report data for most of our empirical work, we adjust reported replacement cost (for all interest rate derivatives) to get an estimate of replacement cost for interest rate swaps. The adjustment involves proportionally reducing the reported replacement cost in the Call Reports by the ratio of the notional value of interest rate swaps to the notional value of all interest rate derivatives except futures. ${ }^{11}$ We experimented with other ratios in the range indicated by in Table 5, but found that the exact assumption did not affect the qualitative results.

\footnotetext{
${ }^{10}$ Other banks in the group reported replacement cost for all interest rate derivatives.

11 We exclude the notional value of futures since futures have a zero replacement cost because they are marked to market.
} 
The ratio of remaining maturity less than one year to notional value is different for interest rate swaps than for other interest rate derivatives. Since we target this ratio in our calibration, we would like to use the ratio for interest rate swaps, rather than for all interest rate derivatives. Therefore, we estimate the ratio for swaps using individual bank data. Banks holding interest rate swaps are assigned to one of five portfolios (as discussed in the subsequent section). We regress the reported remaining maturity ratio for all interest rate derivatives on an intercept and slope dummies for the ratio of swaps to total interest rate derivative of the five portfolios in crosssection. $^{12}$ We use the estimated coefficients from the regression to construct the remaining maturity ratio for swaps. The ratio is relatively constant with a mean of $33.5 \%$ of swap contracts with a remaining maturity of less than one year (see the column headed "Adjusted percent" in Table 3).

Prices are calculated using interest rates on U.S. government securities. There are four implicit assumptions in this calculation. First, swap contracts typically are indexed to LIBOR rather than Treasury Bill rates. LIBOR and Treasury rates are highly but not perfectly correlated. Second, credit risk is unaccounted for in our calculation. Third, we assume that all interest rate swaps are the straightforward "plain vanilla" fixed-for-floating contracts discussed above. Among the other types of swaps that banks trade are amortizing swaps and exotic swaps. Amortizing swaps have a notional value that declines over the life of the swap, much as the principal due on an amortizing loan (such as a home mortgage) declines. These swaps are like plain vanilla swaps with a slightly shorter duration. Exotic swaps are small in notional value, but these swaps may be highly interest-rate sensitive. ${ }^{13}$ Fourth, we assume swaps are held to maturity. Some swap positions are closed out early. To the extent that swaps positions are closed prior to maturity, we

12 The estimated regression is:

remaining maturity $=73.7-0.39(\text { swaps } / \text { total })_{1}-0.46(\text { swaps } / \text { total })_{2}-0.35(\text { swaps } / \text { total })_{3}$

$-0.16(\text { swaps/total })_{4}-0.45(\text { swaps/total })_{5}$

where (swaps/total) is the ratio of swaps to all interest rate derivatives for banks in portfolio $i$. All coefficients are significant at the 5 percent confidence level. The adjusted $R^{2}$ of the regression is 0.23 .

${ }_{13}$ Estimates suggest that the proportion of exotic swaps are small. An example of an exotic swap is the deal between Bankers Trust and Proctor and Gamble. The value of the Bankers Trust-Proctor and Gamble swap depended nonlinearly on 5-year and 30-year Treasury bond interest rates. 
underestimate initial maturity. However, our estimates of interest-rate sensitivity are not affected by this.

\section{Market Value of the Banking System's Interest Rate Swap Position}

\section{A) The Banking System}

In this subsection, we look at the banking system as a whole. Our calibration technique assumes that the maturity structure of new contracts written is constant (Assumption 1). We choose a maturity structure (the $f^{w}$ ) to match the mean reported proportion of swaps with remaining maturity of less than one year. As Table 3 shows, this proportion is relatively constant during the 1990s (the only period for which we have data). Moreover, since there is not a unique set of $f^{\omega}$ consistent with reported remaining maturities, we examine three patterns of $f^{\omega}$. We vary the buckets for swaps with initial maturities greater than one year to produce, roughly speaking flat, U-shaped, and inversely U-shaped maturity structures for contracts of over one-year initial maturity. The flat pattern is $\mathrm{f}^{0}=0.28$ and $\mathrm{f}^{1}=\mathrm{f}^{2}=\mathrm{f}^{3}=\mathrm{f}^{4}=0.18$; the U-shaped pattern is $\mathrm{f}^{0}=$ $0.28, \mathrm{f}^{1}=\mathrm{f}^{4}=0.35$, and $\mathrm{f}^{2}=\mathrm{f}^{3}=0.01$; and the inversely $\mathrm{U}$-shaped pattern is $\mathrm{f}^{0}=0.28, \mathrm{f}^{1}=\mathrm{f}^{4}=$ 0.01 , and $\mathrm{f}^{2}=\mathrm{f}^{3}=0.35$.

Table 6 shows the results for the aggregate swap positions of U.S. commercial banks. For each of the three different calibrations, the table reports the mean fraction of swap contracts that are long, for each initial maturity $\left(1^{0}-1^{4}\right)$. These estimates are used to compute market values using (17) and interest-rate sensitivities using (18). The mean value of these variables for the sixteen quarters, 1990-1993 are shown together with the standard deviation of the interest sensitivity. The ratio of the interest sensitivity to the total equity in the banking system is a means of determining the economic significance of the interest sensitivity. The ratio is given in the final row of the table.

The table shows that banks are, on net, long at short maturities, but short at the long maturities. For all three calibrations, we find that $l^{0}$ and $1^{1}$ equal one while $l^{4}$ is close to zero for two of the three cases. The $\mathrm{l}^{\omega}$ and the $\mathrm{f}^{\omega}$ generate a market value for the aggregate swap portfolio. In the three examples, the mean ratio of estimated market value to replacement cost is 
between ten and thirty percent. This is because banks hold swaps that are both assets and liabilities and replacement cost does not net out the liabilities.

This fact that banks are long in the short maturities means that most of the contracts banks write and most of the contracts they hold at any moment are long. For the U-shaped maturity structure, for example, less than one-quarter of the existing contracts are short (see the last row of Table 6). But, this does not tell us how the market value of their position changes with interest rates since their long contracts are shorter in maturity than their short contracts. The interest-rate sensitivity depends more heavily on the direction of the longer maturities, since the longer maturities are more sensitive to interest rate changes.

Because the banking system is net short in the longer maturities, an increase in interest rates could seriously erode equity in the banking system. We can directly address this question by calculating interest-rate sensitivity. Even for the U-shaped maturity structure, where over 75 percent of the contracts are long, interest-rate sensitivity is negative, indicating that the swap portfolio as a whole is effectively net short. For the three calibrations, interest-rate sensitivity ranges from -33 to -0.24 . This means that a 100 basis point increase in interest rates reduces total bank equity by between $\$ 240$ million and $\$ 33$ billion. To see how big the reported interest-rate sensitivity is, compare it to the total equity in the banking system. Using the intermediate value for interest-rate sensitivity of -12 , a 100 basis point increase in interest rates reduces bank equity by $5 \%$. Interest rates in 1994 went up by between 200 and 300 basis points, indicating that, looking at swaps in isolation, the banking system could have lost roughly $10-15 \%$ of its equity.

The finding that the banks lost significant value on swap holdings does not imply that bank equity fell during 1994. Swap positions may have hedged other bank holdings. Although some banks have taken significant write-downs against equity because of losses on derivatives, systemwide equity has not declined, at least as measured by regulatory accounting rules. ${ }^{14}$ In Section VII, we explore the extent to which swap positions are hedged.

\footnotetext{
14 In April 1994, a variety of news reports indicated that the largest dealer banks reported lower than expected earnings because of derivatives trading losses. More recently, Banc One, Mellon, and other end-user banks have also reported losses on derivatives.
} 
Notice that we report no "standard errors" in Table 6. This is because we use a calibration on the entire population of banks. There is no sampling error (i.e., we use data on all banks). Any errors in our reported values come from errors in our assumptions about the maturity structure of new contracts or errors in our adjustments to the data. One way to assess the robustness of our assumptions is to see how our results change as we vary the assumed maturity structure. The results are qualitatively similar for all three maturity structures. To simplify reporting, henceforth, we show only the flat maturity structure. However, as above, using other maturity structures calibrated on the reported remaining maturity does not qualitatively change our results.

One further point concerns interbank swaps. In our aggregation, we do not net out interbank swaps. Thus, the data we use are not the net position of the banking system, but rather the total gross activity. This does not introduce any problems into our analysis because we aggregate replacement cost. Viewing the industry as a whole, any contract between two banks has a net zero replacement cost. But, our aggregation procedure yields a positive replacement cost. Yet, our procedure yields a zero market value for any interbank swaps.

\section{B) The Distribution of Interest-rate Risk Among Banks}

Swap activity is concentrated at a small number of banks. This suggests that these banks may use swaps for different reasons than other banks. For example, swap positions may differ if some large banks specialize in intermediating interest-rate risk while other banks use swaps for hedging purposes. To examine this, we divide banks into portfolios by size and swap activity.

We form eight portfolios:

(1) the seven large dealer banks listed in a House Banking Committee Minority Staff Report (1993) ${ }^{15}$;

(2) the top thirty banks, by average assets from 1990-1993, excluding the dealer banks in portfolio (1) ${ }^{16}$;

\footnotetext{
${ }^{15}$ The Staff report lists eight major dealer banks, but we exclude Continental Bank because it was controlled by regulators during much of this period (see footnote 6 for a list of the seven other banks).
} 
(3) banks holding swaps with average assets greater than $\$ 5$ billion, but not in portfolios (1) or (2);

(4) banks holding swaps with average assets between $\$ 1$ billion and $\$ 5$ billion;

(5) banks holding swaps with average assets between $\$ 500$ million and $\$ 1$ billion;

(6) banks not holding swaps with average assets greater than $\$ 5$ billion, but not in portfolios (1) or (2);

(7) banks not holding swaps with average assets between $\$ 1$ billion and $\$ 5$ billion;

(8) banks not holding swaps with average assets between $\$ 500$ million and $\$ 1$ billion.

We want to calibrate the swap maturities for the five portfolios that include swaps. To do this, we choose a maturity structure for new contracts (for each portfolio) to match reported remaining maturity, as above. The model assumes that a constant proportion of new contracts are written with each maturity. The only information we have to confirm that banks are writing new contracts in constant proportions is the estimated ratio of swap contracts with less than one year remaining maturity to total swap contracts. ${ }^{17}$ Table 7 shows remaining maturity for the 1990 1993 period, by portfolio. For portfolios $1-3$, the proportion of remaining maturity less than one year is relatively stable. It is less so for the portfolios $4-5$, but these groups hold few swaps (see Table 2). ${ }^{18}$

Table 8 presents results for the five portfolios of banks that hold swaps. Note first that we calibrate the portfolios separately based on the value-weighted remaining maturities. Portfolios 2-

\footnotetext{
${ }^{16}$ Many of the banks in Portfolio 2 conduct swap activity both as end-users and as dealers (this is indicated by the fact that these banks are members of the International Swap Dealers Association). However, in general, these banks have relatively less dealer activity than banks in portfolio 1 (see, for example, Swaps Monitor, July 4, 1994, p. 2).

${ }_{17}$ This columns are just linear transformations of the reported remaining maturity for interest rate derivatives (see footnote 12 for the adjustment regression).

${ }^{18}$ Note that our procedure assumes that the maturity structure of new contracts is constant. For individual banks, the proportion of remaining maturity less than one year is often not constant. Thus, attempting to calibrate individual bank positions introduces too much noise to derive meaningful additional information. This is one reason we form portfolios rather than calibrating on a bank-by-bank basis.
} 
4 have approximately the same remaining maturities, so we use the same assumed maturity structure.

The table shows that large banks are long in the short maturities $\left(l^{0}, 1^{1}, l^{2}\right.$, and $\left.l^{3}\right)$, but short in the longest maturity $\left(1^{4}\right)$. As banks size decreases, this pattern roughly reverses. The portfolio with the smallest banks, portfolio 5 , is short in the short maturities $\left(1^{0}\right.$ and $\left.1^{1}\right)$, and long in the long maturities $\left(l^{2}\right.$ and $\left.\mathrm{l}^{3}\right)$. It is important to keep in mind that the smaller banks have little swap activity. Swaps clearly are not the primary mechanism for small banks to hedge interest-rate risk.

Consistent with large banks holding most swaps, the dollar value of interest sensitivity is highest for Portfolio 1. A 100 basis point increase in interest rates reduces the value of dealer banks by $\$ 9$ billion (prior to any potential gains from hedging). The banks in portfolio 2 would lose only $\$ 3$ billion from a 100 basis point increase in rates. The smaller portfolios would be affected much less by rate changes. However, to assess the impact on banks -- and especially the potential for bank failure -- the relevant measure is the fraction of bank equity lost when rates change. By this measure, the dealer banks in Portfolio 1 are much more exposed to rate increases than banks in any of the other portfolios; the dealer banks lose 23 percent of their equity from each 100 basis point change in rates, while other portfolios lose less than 5 percent of their equity (once again, ignoring hedging).

\section{Hedging Interest-rate Risk From Swaps}

Our evidence shows that the banks, especially large ones, are exposed to interest-rate risk from their swap portfolios, viewed in isolation. We examine the degree to which swaps are hedged in two ways. First, we examine whether the on-balance sheet positions of banks are sensitive to interest rates in such a way as to offset the sensitivity induced by the swap position. This is consistent with banks using swaps to hedge on-balance sheet risk. Second, we look at the extent to which reported net income varies with interest rates and compare this to our results on the interest-rate sensitivity of swap positions. 


\section{A) Maturity Gaps}

Banks are exposed to interest-rate risk from their on-balance sheet activities when their assets do not reprice at the same time as their liabilities. One measure of the interest-rate sensitivity of a bank's balance sheet is its one-year maturity gap. The one-year maturity gap is the difference between the value of assets that reprice within one year and the value of liabilities that reprice within one year, divided by total assets. ${ }^{19}$ For example, if a bank has $\$ 20$ million of assets that reprice within one year and $\$ 30$ million of liabilities that reprice within one year, then the oneyear gap is negative. If interest rates rise, the bank will have to pay higher rates on its $\$ 30$ million of its liabilities and will receive higher rates on only $\$ 20$ million of assets. Thus, in this example, higher rates imply reduced equity value. We get data on the maturity structure of bank onbalance sheet portfolios from the Call Reports.

Finding the one-year maturity gap requires assumptions about the repricing frequency of demand deposits and other liabilities held by consumers. Demand deposits can be instantaneously withdrawn, but evidence suggests that banks do not change their interest rates on deposits when market rates change (see Rosen (1994)). Moreover, NOW accounts also have effective maturities longer than their stated maturities (see Hutchison and Pennacchi (1994)). We use two estimates of the one-year maturity gap. The first assumes that all assets and liabilities have effective maturities equal to their stated maturities (MATGAP). The second adjusts demand deposits and NOW accounts to account for the longer effective maturities of these instruments (MATGAP*). We assume that 40 percent of demand deposits and 40 percent of NOW accounts do not reprice within one year. ${ }^{20}$

Table 9 reports our two measures of maturity gap by year and bank size. The striking fact seen in the table is that dealer banks, Portfolio 1, have a large positive maturity gap by either gap measure, while smaller banks consistently tend to have negative maturity gaps. This suggests that the short swap positions of dealer banks are offset by the on-balance sheet portfolio. When interest rates rise, the swap positions lose value while the on-balance sheet items gain in value.

\footnotetext{
${ }^{19}$ Floating rate loans reprice at the frequency that the floating interest rate is recomputed.

${ }^{20}$ This adjustment appears consistent with the "management adjustments" that Banc One uses, as reported in its 1993 Annual Report.
} 
Unfortunately, the one-year maturity gap is too coarse a measure to determine the net interestrate sensitivity of dealer banks as a group.

The large nondealer banks (Portfolio 2) have relatively small (in magnitude) maturity gaps. This suggests that an increase in interest rates reduces the value of the swap portfolio, but this is not be offset by changes in the value of on-balance sheet items. Smaller banks tend to have negative maturity gaps, but fairly small swap exposures.

\section{B) Using Net Income to Estimate the Extent of Swap Hedging}

We can take advantage of accounting identities to derive a more exact measure of the degree to which banks' swap exposures offset exposure elsewhere in the banks' portfolios. Banks report swap activity in two ways. Banks are allowed by regulators to declare some swaps to be hedging other bank activities (such as fixed-rate loans or interest-rate futures). Banks use "hedge accounting" to value swaps that are declared as hedges. Gains and losses on swaps in the hedge account are recognized when gains and losses on the instruments that the swaps hedge are recognized. In other words, the reported net income on hedge-account swaps and the instruments they hedge is zero. Other swaps are considered to be in the bank's trading account. Swaps in the trading account are reported at market value. When interest rates move, only the change in value of trading-account swaps is reported as net income.

This yields the accounting identity:

$$
\begin{aligned}
\text { Net Income }= & \text { Net Income of the Unhedged Nonswap Activities } \\
& + \text { Change in (Market) Value of Unhedged Swaps } \\
& + \text { Net Income of Hedged Swaps } \\
& + \text { Net Income of Hedged Nonswap Activities. }
\end{aligned}
$$

Because of the accounting rules, the last two terms sum to zero. In the previous section, we calculate the change in market value of bank swap positions when interest rates change. We do not know how the net income of the unhedged nonswap activities varies with interest rates. We 
assume that the relationship between net income and swap interest-rate sensitivity is given by the regression:

$$
N I_{t, p}=\alpha+\beta \frac{d M V_{t, p}}{d r_{t, p}} \Delta r_{t}+\Psi X_{t, p}+\varepsilon_{t, p}
$$

where $\mathrm{NI}_{t, p}$ is reported net income at date $t$ for portfolio $\mathrm{p}, \mathrm{X}_{t, \mathrm{p}}$ is a vector of other independent variables that affect reported net income of unhedged nonswap activities, and $\varepsilon_{t, p}$ is a white-noise error term. The regression coefficient $\beta$ measures the proportion of the swap portfolio that is unhedged.

Since banks have nonswap instruments that are affected by interest rates, but that may not be hedged by swaps, reported net income can change with interest rates from factors other than a change in the value of the swap portfolio. To account for this, we include the change in interest rates as part of $X_{t, p}$. Net income is also affected by the default rate on loans. The default rate on loans may be correlated with interest rates (since both depend on macroeconomic factors), so we include loan chargeoffs in $\mathrm{X}_{\mathrm{L}, \mathrm{p}}$. All the variables except the change in interest rates are divided by total assets to reduce heteroskedasticity.

Table 10 presents the regression results. We pool the eight portfolios in the regressions in columns $1-3$. Notice that the change in interest rates and chargeoffs are both significant, with the expected signs (see columns 1 and 2). The key regression, in column 3, has size dummies for each portfolio and size dummies interacted with the interest-rate sensitivity variable calculated above for the five portfolios with swaps. In this regression, we focus on the coefficients on the interaction term. For the dealer banks, the coefficient is 0.09 . This means that nine percent of the swap exposure is unhedged. This is consistent with their swap position being short and their onbalance sheet position being long (positive maturity gap). The large, nondealer banks (Portfolio 2) have an exposure of 47 percent. This suggests that a much smaller fraction of their swap portfolio is hedged. Once again, this is consistent with recent reports of losses on swaps by these banks. Examples in the fourth quarter of 1994 include Bank One which announced losses of $\$ 170$ million on "interest-rate bets;" Mellon Bank which took a $\$ 130$ million charge to cover derivatives losses; and KeyCorp which took a $\$ 100$ million charge (Wall Street Journal, January 
9, 1995, p. A9). The coefficients on the interaction term for portfolios $3-5$ are insignificant, possibly because these banks hold few swaps.

To test whether the inclusion of banks with little or no swap activity affects the coefficients for the large banks with swaps, column 4 of Table 10 presents the results of a regression including only portfolios 1 and 2 . The coefficients are qualitatively similar to those in column 3. Comparing regressions 3 and 4 to regression 2 indicates that the inclusion of the interest sensitivity variables and the portfolio dummies increases predictive power by about twelve percentage points.

The net exposure of a bank from its swap portfolio to changes in interest rates depends on the degree to which its swap portfolio is hedged and the size of its swap portfolio relative to equity. From Table 8, we know that when interest rates rise by 100 basis points, banks in Portfolio 1 lose 23 percent of their equity value from swaps. Table 10 indicates, however, that this loss is offset by an approximately 21 percent gain elsewhere in the bank's portfolio, leaving a net loss of 2 percent of equity, that is $\$ 800$ million. Similarly, Portfolio 2 loses 47 percent of 4 percent of equity, that is, 2 percent of equity, that is $\$ 2.0$ billion.

\section{C) Who are Banks Trading With and Hedging With?}

On net, the banking system, and specifically, dealer banks, hold unhedged positions in swaps. This raises two issues. First, who takes the other side of the swap trades? And, second, since banks are hedging their swap positions, who are they hedging with? The answers to these questions would shed important light on why the swap market exists in the form it does.

With respect to the first question, the biggest holders of swaps outside of U.S. banks are foreign banks. As shown in Table 1, many of the largest swap positions are held by non-U.S. banks. We do not have enough information to know whether the non-U.S. banks are net long or short. However, we do know that some other end users of swaps seem likely to prefer long positions in the swap market. Nonfinancial U.S. corporations are said to be candidates to take long positions in swaps (see, for example, Swaps Monitor, July 4, 1994, p. 3). In addition, U.S. government agencies, including Fannie Mae, Sallie Mae, and the Federal Home Loan Bank of San Francisco, are significant 
end users. These agencies have long-term fixed-rate assets such as home mortgages, making them likely to be long in swaps. We do not know whether it is these customers that are driving the net short swap positions of banks.

Now we turn to the second question of who is willing to take the interest-rate risk from the swap activity that banks are hedging. Interest-rate risk is nondiversifiable, so if banks are hedging then the risk which was transferred to banks by customers is somehow being repackaged and possibly sold back to the same customers. If, in fact, the same customers are buying back the risk, via futures market positions, then the reason for the existence of the swap market is economies of scale or scope. Banks are able to repackage risk in ways that customers prefer to hold.

Another possible counterparty for banks is foreign banks. Some of these banks are stateowned or otherwise protected from failure. This means that risk-taking by these foreign banks may be subsidized by their governments. This would make them a natural repository for any nondiversifiable risk, including interest-rate risk. Since most of the large U.S. bank swap dealers are "too big to fail," it is not clear why foreign banks, but not U.S. banks, should hold the residual interest rate risk.

A remaining possibility is that banks' swap positions are less hedged than our regression results imply. There are two ways that our results can overestimate hedging. First, if banks underestimate declines in the market value of their swaps, perhaps because they underestimate potential credit losses, then we will underestimate the interest-rate sensitivity of their swap portfolios (reports of higher-thanexpected credit losses on derivatives have recently appeared, Wall Street Journal). Then, the coefficient on the interest-rate sensitivity term in the regressions is underestimated.

A second way that we can overestimate hedging is if net income is smoothed relative to interest rates. It is well known that banks smooth income (see, e.g., Greenwalt and Sinkey (1988)). Smoothing would occur if banks underestimated the unhedged losses and gains on derivatives. If smoothing is a major problem then, again, the coefficient on the interest-rate sensitivity term in the regressions is underestimated. Note that if this is a problem, then the recent rise in interest rates might have caused large unreported losses at large banks. 


\section{Conclusions}

Assessing risk requires information. There is very little publicly available information on the swap positions of banks. This means that it is very difficult to estimate the exposure of banks to interest rate movements. Outside investors cannot impose discipline on banks without additional information. The information necessary to better assess the risks is available, but not reported. This forces investors and society as a whole to rely on bank regulators and examiners. Regulators and examiners have access to the relevant information when they monitor the derivatives positions of individual banks. Unlike regulation of bank loan positions, there is no inherent asymmetric information between banks and others about the risk of swap positions (except for concerns about credit quality). This means that if sufficient information is made public, investors could assess risk as accurately as bank insiders and examiners.

How much information should banks be required to publicly report? We do not know. There are two issues. One is permitting investors to accurately estimate market value of bank swap positions to make investments decisions. A second issue is to assess systemic risk, in addition to individual-institution risk. Systemic risk requires looking at the banking system as a whole. What we are concerned with is the possibility that a number of banks will suffer large losses on swaps at the same time. At a minimum, releasing the maturity structure of swaps and other derivative positions on a quarterly basis -- comparable to what banks currently release about on-balance sheet activities -- would allow a more detailed estimation of risk at little cost.

In this paper, we are forced to make several assumptions about maturity to look at systemic issues. With our assumptions, we calculate market values and interest-rate sensitivities of swap positions in the banking industry. We find that the banking system as a whole, and dealer banks in particular, are exposed to interest rate increases. However, we also find that banks seem to have hedged most of the risk. Our results suggest that there should be little concern about systemic risk from swaps, subject to the limitations of our data.

A risk that we are unable to assess with the publicly available data concerns short-term gambles that banks take. Banks attempt to profit from what they see as short-term aberrations in market price. To profit, banks take short-term speculative positions on specific interest rate 
events, such as a widening of the LIBOR-prime spread. Banks plan to close these positions quickly, especiaily if the market moves against them. Only if information were released on a frequent, perhaps daily, basis could these positions be monitored by outsiders. But, it seems less likely that these types of strategies would contribute significantly to systemic risk. If many banks attempt to make the same bet on a specific event, they will quickly move market prices, eliminating the perceived profit opportunity.

One final concern is that our conclusions may be premature. The nature of the swaps market might change since swaps are a relatively new product. Swaps have been very profitable for dealer banks which may have mitigated the incentives for large banks with entrenched managements to take on risk (see Gorton and Rosen (1995)). Recent problems at Bankers Trust suggest that the industry may be entering a new less profitable phase. Since swaps are opaque regulators and others must be aware that once swaps are no longer as profitable, large dealer banks may begin to use them as vehicles for adding risk. 


\section{References}

Bank for International Settlements (1992), "Recent Developments in International Interbank Relations," Report Prepared by a Working Group Established by the Central Banks of the Group of Ten Countries [The Promisel Report], Basle, Switzerland, Oct. 1992.

Bank of England (1993), Derivatives: Report of an Internal Working Group, April.

Bank of England (1987), Potential Credit Exposure on Interest Rate and Foreign Exchange Related Instruments, March.

Basle Committee on Banking Supervision (1993A), "The Prudential Supervision of Netting, Market Risks, and Interest Rate Risk," Preface to Consultative Proposal, April.

Basle Committee on Banking Supervision (1993B), "The Supervisory Recognition of Netting for Capital Adequacy Purposes," Consultative Proposal, April.

Basle Committee on Banking Supervision (1993C), "The Supervisory Treatment of Market Risks," Consultative Proposal, April.

Basle Committee on Banking Supervision (1993D), "Measurement of Banks' Exposure to Interest Rate Risk," Consultative Proposal, April.

Board of Governors of the Federal Reserve System, Federal Deposit Insurance Corporation, and Office of the Comptroller of the Currency, "Derivative Product Activities of Commercial Banks," Joint Study Conducted in Response to Questions Posed by Senator Riegle on Derivative Products, Washington D.C., Jan. 27,1993.

Commodity Futures Trading Commission, "OTC Derivative Markets and Their Regulation," Report of the Commodity Futures Trading Commission, Washington D.C., Oct. 1993.

Dow, James and Gary Gorton (1994), "Noise Trading, Delegated Portfolio Management, and Economic Welfare," National Bureau of Economic Research Working Paper No. 4858.

Gorton, Gary and Richard J. Rosen (1995), "Corporate Control, Portfolio Choice, and the Decline of Banking," working paper, University of Pennsylvania.

Greenwalt, Mary Brady and Joseph F. Sinkey, "Bank Loan-Loss Provisions and the IncomeSmoothing Hypothesis: An Empirical Analysis, 1976-1984," Journal of Financial Services Research 1, 301-318.

Group of Thirty, Global Derivatives Study Group (1993A), "Derivatives: Practice and Principles," July.

Group of Thirty, Global Derivatives Study Group (1993B), "Derivatives: Practices and Principles, Appendix I: Working Papers," July.

Group of Thirty, Global Derivatives Study Group (1994), "Derivatives: Practices and Principles, Appendix II: Survey of Industry Practice," March.

Hadley, G. (1964), Nonlinear and Dynamic Programming (Addison-Wesley Publishing).

House Banking Committee Minority Staff (1993), Financial Derivatives, November 1993. 
Hutchison, David E. and George Pennacchi (1994), "Measuring Rents and Interest Rate Risk in Imperfect Financial Markets: The Case of Retail Bank Deposits," working paper, University of Illinois.

Rosen, Richard J. (1994), "What Goes Up Must Come Down? Asymmetries and Persistence in Bank Deposit Interest Rates," working paper, University of Pennsylvania and the Federal reserve Board.

U.S. Comptroller of the Currency, "National Bank Participation in the Financial Futures and Forward Placement Market," Banking Circular BC-79 (3" ${ }^{\text {rd }}$. Rev.), OCC, April 19,1993.

U.S. Comptroller of the Currency, "Risk Management of Financial Derivatives," Banking Circular BC-277, OCC, Oct. 27,1993.

U.S. Congress, House Committee on Banking, Finance, and Urban Affairs (1993), Hearings on Safety and Soundness Issues Relating to Bank Derivatives Activities, $103 \mathrm{~d}$ Congress, $1^{\text {th }}$ Session (October 28,1993), Serial 103-88.

U.S. Government Accounting Office (1994), Financial Derivatives: Action Needed to Protect the Financial System GAOIGGD-94-133. 


\section{Figure 1 Swap Examples}

Bank in Long Position: Pays Fixed and Receives Floating

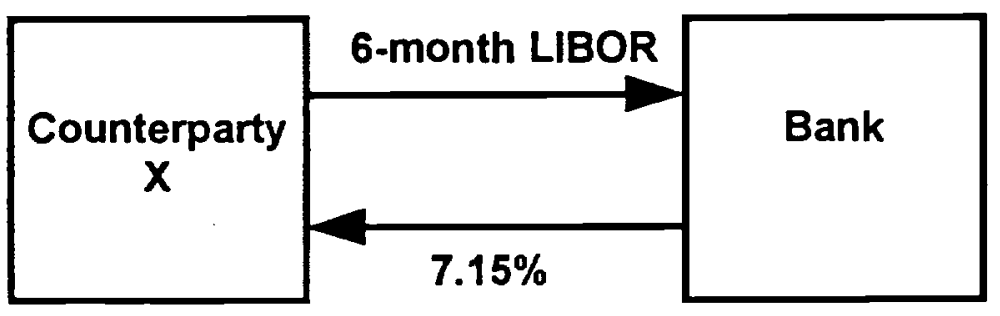

Bank in Short Position: Pays Floating and Receives Fixed

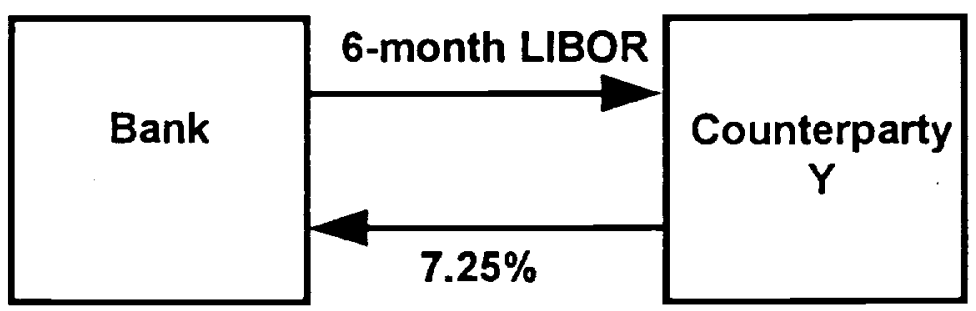

Bank in Hedged Position

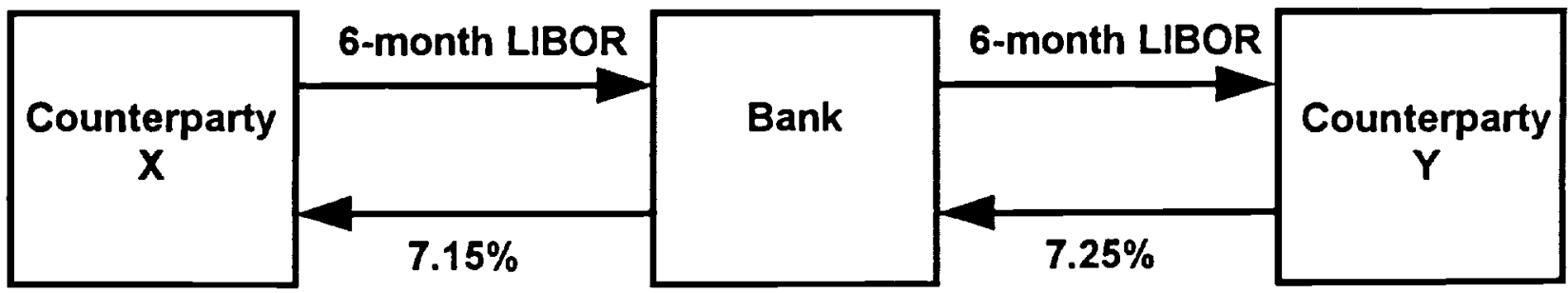


Table 1

World's Major Interest Rate Swap Firms

(Year end 1992)

\begin{tabular}{|c|c|c|}
\hline Rank & Firm & $\begin{array}{c}\text { Outstandings } \\
\text { (\$billions) }\end{array}$ \\
\hline 1 & Chemical Bank & $\$ 389.7$ \\
\hline 2 & J.P. Morgan & 367.7 \\
\hline 3 & Societe Generale & 345.9 \\
\hline 4 & Compagnie Financiere de Paribus & 342.7 \\
\hline 5 & Credit Lyonnais & 272.8 \\
\hline 6 & Merrill Lynch & 265.0 \\
\hline 7 & Bankers Trust & 255.7 \\
\hline 8 & Barclays Bank & 247.4 \\
\hline 9 & Chase Manhattan & 222.2 \\
\hline 10 & Citicorp & 217.0 \\
\hline 11 & Bank of America & 191.1 \\
\hline 12 & Credit Agricole & 181.7 \\
\hline 13 & Banque Indosuez & 174.1 \\
\hline 14 & Banque Nationale de Paris & 160.1 \\
\hline 15 & Westpac & 147.8 \\
\hline 16 & Salomon Brothers & 144.0 \\
\hline 17 & Caisse des Depots & 111.8 \\
\hline 18 & First Chicago & 74.8 \\
\hline 19 & Bank of Nova Scotia & 73.8 \\
\hline 20 & Banque Bruxelles Lambert & 56.6 \\
\hline & Total of Top 20 & $4,241.9$ \\
\hline & & \\
\hline
\end{tabular}

Source: The World's Major Derivatives Dealers, Swaps Monitor Publications (1993). 
Table 2

Interest Rate Swap Positions of U.S. Commercial Banks

(Year end 1985-1993)

Panel A: All Banks

\begin{tabular}{|c|c|c|c|c|c|}
\hline Year & $\begin{array}{c}\text { Number of } \\
\text { Banks }\end{array}$ & $\begin{array}{c}\text { \% of Banks } \\
\text { Engaged in } \\
\text { Swaps }\end{array}$ & $\begin{array}{c}\text { Total Swap } \\
\text { Notional Value } \\
\text { (\$ billions) }\end{array}$ & $\begin{array}{c}\text { Ratio of Swap } \\
\text { Notional Value } \\
\text { to Total Assets } \\
\text { (percentage) }\end{array}$ & $\begin{array}{c}\text { Ratio of Swap } \\
\text { Notional Value to } \\
\text { Book Value of Equity } \\
\text { (percentage }\end{array}$ \\
\hline 1985 & 11,035 & $1.4 \%$ & 186.15 & $6.9 \%$ & $111.2 \%$ \\
\hline 1986 & 10,516 & 1.7 & 366.63 & 12.6 & 204.3 \\
\hline 1987 & 10,174 & 1.8 & 715.50 & 24.0 & 399.3 \\
\hline 1988 & 9,792 & 1.9 & 930.41 & 29.9 & 477.2 \\
\hline 1989 & 9,521 & 1.9 & $1,349.32$ & 41.2 & 664.8 \\
\hline 1990 & 9,284 & 2.0 & $1,716.78$ & 51.1 & 793.4 \\
\hline 1991 & 9,180 & 2.2 & $1,755.85$ & 51.2 & 765.6 \\
\hline 1992 & 8,833 & 2.2 & $2,121.97$ & 61.0 & 813.3 \\
\hline 1993 & 8,596 & 2.3 & $2,946.26$ & 80.2 & $1,003.0$ \\
\hline
\end{tabular}

Panel B: Dealer Banks

\begin{tabular}{|c|c|c|c|c|c|}
\hline Year & $\begin{array}{c}\text { Number of } \\
\text { Banks } \\
\text { in Group }\end{array}$ & $\begin{array}{c}\% \text { of Banks } \\
\text { Engaged in } \\
\text { Swaps }\end{array}$ & $\begin{array}{c}\text { Total Swap } \\
\text { Notional Value } \\
\text { (\$ billions) }\end{array}$ & $\begin{array}{c}\text { Ratio of Swap } \\
\text { Notional Value } \\
\text { to Total Assets } \\
\text { (percentage) }\end{array}$ & $\begin{array}{c}\text { Ratio of Swap } \\
\text { Notional Value to } \\
\text { Book Value of Equity } \\
\text { (percentage) }\end{array}$ \\
\hline 1985 & 7 & $100 \%$ & 137.31 & $22.8 \%$ & $424.7 \%$ \\
\hline 1986 & 7 & 100 & 279.81 & 43.7 & 781.0 \\
\hline 1987 & 7 & 100 & 559.08 & 86.9 & 1787.0 \\
\hline 1988 & 7 & 100 & 713.29 & 110.9 & 1995.2 \\
\hline 1989 & 7 & 100 & 1016.57 & 155.0 & 3123.8 \\
\hline 1990 & 7 & 100 & 1285.65 & 198.0 & 3682.1 \\
\hline 1991 & 7 & 100 & 1268.22 & 195.8 & 3531.7 \\
\hline 1992 & 7 & 100 & 1614.24 & 251.5 & 3742.6 \\
\hline 1993 & 7 & 100 & 2264.30 & 318.4 & 4461.8 \\
\hline
\end{tabular}

Panel C: Top 30 Banks Excluding Dealer Banks

\begin{tabular}{|c|c|c|c|c|c|}
\hline Year & $\begin{array}{c}\text { Number of } \\
\text { Banks in } \\
\text { Group }\end{array}$ & $\begin{array}{c}\text { \% of Banks } \\
\text { Engaged in } \\
\text { Swaps }\end{array}$ & $\begin{array}{c}\text { Total Swap } \\
\text { Notional Value } \\
\text { (\$ billions) }\end{array}$ & $\begin{array}{c}\text { Ratio of Swap } \\
\text { Notional Value } \\
\text { to Total Assets } \\
\text { (percentage) }\end{array}$ & $\begin{array}{c}\text { Ratio of Swap } \\
\text { Notional Value to } \\
\text { Book Value of Equity } \\
\text { (percentage) }\end{array}$ \\
\hline 1985 & 23 & 100 & 31.50 & $3.8 \%$ & $70.2 \%$ \\
\hline 1986 & 23 & 96 & 61.49 & 7.0 & 128.4 \\
\hline 1987 & 23 & 96 & 110.17 & 12.5 & 232.1 \\
\hline 1988 & 23 & 96 & 152.43 & 17.1 & 303.7 \\
\hline 1989 & 23 & 100 & 233.68 & 23.7 & 417.2 \\
\hline 1990 & 23 & 100 & 305.42 & 29.6 & 496.9 \\
\hline 1991 & 23 & 100 & 348.53 & 34.0 & 548.6 \\
\hline 1992 & 23 & 100 & 364.33 & 34.9 & 482.6 \\
\hline 1993 & 23 & 100 & 494.06 & 45.6 & 591.7 \\
\hline
\end{tabular}


Table 2 Continued

Panel D: Banks With Total Assets Exceeding \$5 Billion, but not in Top 30 Banks

\begin{tabular}{|c|c|c|c|c|c|}
\hline Year & $\begin{array}{c}\text { Number of } \\
\text { Banks in } \\
\text { Group }\end{array}$ & $\begin{array}{c}\text { \% of Banks } \\
\text { Engaged in } \\
\text { Swaps }\end{array}$ & $\begin{array}{c}\text { Total Swap } \\
\text { Notional Value } \\
\text { (\$ billions) }\end{array}$ & $\begin{array}{c}\text { Ratio of Swap } \\
\text { Notional Value } \\
\text { to Total Assets } \\
\text { (percentage) }\end{array}$ & $\begin{array}{c}\text { Ratio of Swap } \\
\text { Notional Value to } \\
\text { Book Value of Equity } \\
\text { (percentage) }\end{array}$ \\
\hline 1985 & 57 & 96 & 11.82 & $2.6 \%$ & $43.8 \%$ \\
\hline 1986 & 57 & 96 & 15.36 & 3.1 & 52.2 \\
\hline 1987 & 59 & 97 & 32.65 & 6.3 & 109.1 \\
\hline 1988 & 59 & 97 & 39.46 & 7.0 & 115.5 \\
\hline 1989 & 59 & 97 & 43.03 & 7.2 & 118.0 \\
\hline 1990 & 59 & 97 & 56.51 & 9.0 & 151.0 \\
\hline 1991 & 60 & 97 & 65.80 & 10.8 & 166.1 \\
\hline 1992 & 61 & 97 & 80.10 & 12.4 & 175.0 \\
\hline 1993 & 59 & 97 & 115.79 & 16.8 & 221.5 \\
\hline
\end{tabular}

Panel E: Banks with Total Assets Between $\$ 1$ Billion and $\$ 5$ Billion

\begin{tabular}{|c|c|c|c|c|c|}
\hline Year & $\begin{array}{c}\text { Number of } \\
\text { Banks in } \\
\text { Group }\end{array}$ & $\begin{array}{c}\text { \% of Banks } \\
\text { Engaged in } \\
\text { Swaps }\end{array}$ & $\begin{array}{c}\text { Total Swap } \\
\text { Notional Value } \\
\text { (\$ billions) }\end{array}$ & $\begin{array}{c}\text { Ratio of Swap } \\
\text { Notional Value } \\
\text { to Total Assets } \\
\text { (percentage) }\end{array}$ & $\begin{array}{c}\text { Ratio of Swap } \\
\text { Notional Value to } \\
\text { Book Value of Equity } \\
\text { (percentage) }\end{array}$ \\
\hline 1985 & 140 & 52 & 1.38 & $0.5 \%$ & $8.1 \%$ \\
\hline 1986 & 140 & 53 & 2.04 & 0.7 & 11.4 \\
\hline 1987 & 148 & 53 & 2.75 & 1.0 & 14.0 \\
\hline 1988 & 150 & 53 & 6.61 & 2.2 & 33.8 \\
\hline 1989 & 150 & 53 & 8.10 & 2.7 & 38.1 \\
\hline 1990 & 150 & 53 & 7.76 & 2.5 & 34.6 \\
\hline 1991 & 148 & 53 & 7.46 & 2.3 & 32.0 \\
\hline 1992 & 147 & 52 & 7.94 & 2.4 & 31.3 \\
\hline 1993 & 138 & 52 & 12.81 & 3.9 & 47.7 \\
\hline
\end{tabular}

Panel F: Banks with Total Assets Between $\$ 500$ Million and $\$ 1$ Billion

\begin{tabular}{|c|c|c|c|c|c|}
\hline Year & $\begin{array}{c}\text { Number of } \\
\text { Banks in } \\
\text { Group }\end{array}$ & $\begin{array}{c}\text { \% of Banks } \\
\text { Engaged in } \\
\text { Swaps }\end{array}$ & $\begin{array}{c}\text { Total Swap } \\
\text { Notional Value } \\
\text { (\$ billions) }\end{array}$ & $\begin{array}{c}\text { Ratio of Swap } \\
\text { Notional Value } \\
\text { to Total Assets } \\
\text { (percentage) }\end{array}$ & $\begin{array}{c}\text { Ratio of Swap } \\
\text { Notional Value to } \\
\text { Book Value of Equity } \\
\text { (percentage }\end{array}$ \\
\hline 1985 & 149 & 0.20 & 0.16 & $0.2 \%$ & $2.8 \%$ \\
\hline 1986 & 150 & 0.20 & 0.41 & 0.5 & 6.7 \\
\hline 1987 & 153 & 0.22 & 0.54 & 0.7 & 8.9 \\
\hline 1988 & 154 & 0.22 & 0.82 & 0.9 & 12.5 \\
\hline 1989 & 155 & 0.23 & 1.14 & 1.2 & 15.9 \\
\hline 1990 & 155 & 0.22 & 1.34 & 1.3 & 17.7 \\
\hline 1991 & 147 & 0.22 & 1.05 & 1.1 & 14.1 \\
\hline 1992 & 150 & 0.22 & 1.04 & 1.0 & 12.1 \\
\hline 1993 & 151 & 0.21 & 1.39 & 1.2 & 14.8 \\
\hline
\end{tabular}

Source: Call Reports of Income and Condition 
Table 3

Notional Value, Replacement Value, Remaining Maturity, Interest Rates (All Banks)

\begin{tabular}{|c|c|c|c|c|c|c|}
\hline Year & Quarter & $\begin{array}{l}\text { Swap Notional Value } \\
\text { (\$billions) }\end{array}$ & $\begin{array}{c}\text { Replacement } \\
\text { Cost } \\
\text { (\$billions) }\end{array}$ & $\begin{array}{l}\text { Percent of total } \\
\text { notional value with } \\
\text { less than } 1 \text { year } \\
\text { remaining maturity }\end{array}$ & $\begin{array}{l}\text { Adjusted percent of } \\
\text { total notional value } \\
\text { with less than } 1 \text { year } \\
\text { remaining maturity }\end{array}$ & $\begin{array}{l}\text { Three Month } \\
\text { Treasury Bill } \\
\text { Rate }\end{array}$ \\
\hline 1990 & 1 & 1451.2 & 26.4 & 49.9 & 30.7 & 8.58 \\
\hline 1990 & 2 & 1492.6 & 25.9 & 49.3 & 31.1 & 8.38 \\
\hline 1990 & 3 & 1615.9 & 24.2 & 49.7 & 30.6 & 7.94 \\
\hline 1990 & 4 & 1716.8 & 27.7 & 49.6 & 31.5 & 7.23 \\
\hline 1991 & 1 & 1564.1 & 29.0 & 47.4 & 30.4 & 6.28 \\
\hline 1991 & 2 & 1577.6 & 28.0 & 47.2 & 30.0 & 5.90 \\
\hline 1991 & 3 & 1816.1 & 38.7 & 49.3 & 31.3 & 5.51 \\
\hline 1991 & 4 & 1755.9 & 51.1 & 48.5 & 27.0 & 4.24 \\
\hline 1992 & 1 & 1819.8 & 42.2 & 49.1 & 29.6 & 4.21 \\
\hline 1992 & 2 & 1964.8 & 50.8 & 50.0 & 30.0 & 3.80 \\
\hline 1992 & 3 & 2065.2 & 61.9 & 50.1 & 29.2 & 3.00 \\
\hline 1992 & 4 & 2122.0 & 52.6 & 50.3 & 30.2 & 3.33 \\
\hline 1993 & 1 & 2270.3 & 62.6 & 50.7 & 30.2 & 3.04 \\
\hline 1993 & 2 & 2582.3 & 65.2 & 51.8 & 30.1 & 3.17 \\
\hline 1993 & 3 & 2786.1 & 73.4 & 51.8 & 30.0 & 3.04 \\
\hline 1993 & 4 & 2946.3 & 76.1 & 51.5 & 30.5 & 3.16 \\
\hline
\end{tabular}

Source: Call Reports of Income and Condition 
Notional Value and Replacement Value: Examples

Panel A: Floating Rate $=6 \%$

\begin{tabular}{|c|c|c|c|c|c|}
\hline $\begin{array}{c}\text { Notional } \\
\text { Value }\end{array}$ & Position & Fixed Rate & $\begin{array}{c}\text { Long } \\
\text { Contracts } \\
(\$)\end{array}$ & $\begin{array}{c}\text { Short } \\
\text { Contracts } \\
(\$)\end{array}$ & $\begin{array}{c}\text { Price Per } \\
\$ 1 \text { of } \\
\text { Notional } \\
\text { Value }\end{array}$ \\
\hline$\$ 3$ million & Long & $7 \%$ & $\$ 3$ million & 0 & -0.009 \\
\hline$\$ 1$ million & Short & $5 \%$ & 0 & $\$ 1$ million & 0.009 \\
\hline$\$ 1$ million & Short & $8 \%$ & 0 & $\$ 1$ million & -0.019 \\
\hline
\end{tabular}

Panel B: Floating Rate $=5 \%$

\begin{tabular}{|c|c|c|c|c|c|}
\hline $\begin{array}{c}\text { Notional } \\
\text { Value }\end{array}$ & Position & Fixed Rate & $\begin{array}{c}\text { Long } \\
\text { Contracts } \\
(\$)\end{array}$ & $\begin{array}{c}\text { Short } \\
\text { Contracts } \\
(\$)\end{array}$ & $\begin{array}{c}\text { Price Per } \\
\$ 1 \text { of } \\
\text { Notional } \\
\text { Value }\end{array}$ \\
\hline$\$ 3$ million & Long & $7 \%$ & $\$ 3$ million & 0 & -0.019 \\
\hline$\$ 1$ million & Short & $5 \%$ & 0 & $\$ 1$ million & 0.0 \\
\hline$\$ 1$ million & Short & $8 \%$ & 0 & $\$ 1$ million & -0.029 \\
\hline
\end{tabular}

Note: Price $=(1-\Gamma)$ where $\Gamma$ is the current value of a one-year bond with a coupon rate equal to the fixed rate. 
Table 5

Notional Swap Value and Replacement Cost From Bank Annual Reports

(Data for 1993)

\begin{tabular}{|l|c|c|c|c|}
\hline \multicolumn{1}{|c|}{ Firm } & $\begin{array}{c}\text { Notional Swap } \\
\text { Value } \\
\text { (\$ billions) }\end{array}$ & $\begin{array}{c}\text { Replacement } \\
\text { Cost } \\
\text { (\$illions) }\end{array}$ & $\begin{array}{l}\text { Ratio of Reported } \\
\text { Swap Replacement } \\
\text { Cost to Reported } \\
\text { Swap Notional Value }\end{array}$ & $\begin{array}{l}\text { Ratio of } \\
\text { Replacement } \\
\text { Cost to } \\
\text { Notional Value } \\
\text { for Call } \\
\text { Reports }\end{array}$ \\
\hline Chemical Bank & 667.9 & 8.6 & 1.29 & 1.20 \\
\hline J.P. Morgan & 567.7 & N/A & N/A & N/A \\
\hline Bankers Trust & 349.7 & 9.57 & 2.74 & 1.95 \\
\hline Citicorp & 244.3 & 6.8 & 2.78 & 1.46 \\
\hline $\begin{array}{l}\text { Bank of } \\
\text { America }\end{array}$ & 223.4 & 6.85 & 3.07 & 2.40 \\
\hline $\begin{array}{l}\text { Chase } \\
\text { Manhattan }\end{array}$ & 178.7 & 5.6 & 3.13 & 1.77 \\
\hline First Chicago & 114.9 & N/A & N/A & N/A \\
\hline $\begin{array}{l}\text { Continental } \\
\text { Illinois }\end{array}$ & 47.4 & 1.44 & 3.04 & 1.77 \\
\hline Banc One & 36.4 & 0.29 & 0.80 & 0.85 \\
\hline Republic Bank & 25.9 & 0.53 & 2.04 & 1.89 \\
\hline First Union & 16.8 & 0.31 & 1.83 & 0.81 \\
\hline Mellon Bank & 13.6 & N/A & N/A & N/A \\
\hline $\begin{array}{l}\text { Bank of New } \\
\text { York }\end{array}$ & 10.8 & N/A & N/A & N/A \\
\hline Bank of Boston & 10.2 & N/A & N/A & N/A \\
\hline First Interstate & 9.3 & N/A & N/A & N/A \\
\hline Wells Fargo & 2.1 & N/A & N/A & N/A \\
\hline & & & & \\
\hline
\end{tabular}

Source: Individual Bank Annual Reports 
Table 6

Estimates of Market Value and Interest Sensitivity: All Banks

\begin{tabular}{|c|c|c|c|}
\hline & \multicolumn{3}{|c|}{ Maturity Structure of New Contracts } \\
\hline & $\begin{array}{c}\text { Flat } \\
f^{0}=0.28 \\
f^{1}=f^{2}=f^{3}=f^{4}=0.18\end{array}$ & $\begin{array}{c}\text { U-Shaped } \\
f^{0}=0.28 \\
f^{1}=f^{4}=0.35 \\
f^{2}=f^{3}=0.01\end{array}$ & $\begin{array}{c}\text { Inverse U-Shaped } \\
\qquad \begin{array}{c}f^{0}=0.28 \\
f^{1}=f^{4}=0.01 \\
f^{2}=f^{3}=0.35\end{array}\end{array}$ \\
\hline Estimated $I^{0}, I^{1}, I^{2}, I^{3}, I^{4}$ & $\begin{array}{c}P^{0}=I^{1}=I^{2}=1 \\
P^{3}=0.672 \\
I^{4}=0.0\end{array}$ & $\begin{array}{c}I^{0}=I^{1}=I^{2}=I^{3}=1 \\
I^{4}=0.39\end{array}$ & $\begin{aligned} P^{0} & =1^{1}=1^{2}=1 \\
1^{3} & =1^{4}=0.0\end{aligned}$ \\
\hline $\begin{array}{c}\text { Swap Notional Value' } \\
\text { (\$billions) }\end{array}$ & 1971.66 & 1971.66 & 1971.66 \\
\hline $\begin{array}{l}\text { Adjusted Replacement } \\
\text { Value }^{1} \text { (\$billions) }\end{array}$ & 46.00 & 46.00 & 46.00 \\
\hline $\begin{array}{c}\text { Estimated Market Value' } \\
\text { (\$billions) }\end{array}$ & 8.88 & 4.44 & 13.55 \\
\hline $\begin{array}{c}\text { Estimated Interest } \\
\text { Sensitivity }{ }^{1,2} \\
\text { (\$billions) }\end{array}$ & -11.8 & -0.24 & -33.2 \\
\hline $\begin{array}{l}\text { Standard Deviation of } \\
\text { Interest Sensitivity }{ }^{\dagger} \\
\text { (\$billions) }\end{array}$ & 3.14 & 2.41 & 7.48 \\
\hline $\begin{array}{l}\text { Percent Change in } \\
\text { Equity Value }{ }^{1} \text { per } 100 \\
\text { basis point change in the } \\
\text { interest rate (\%) }\end{array}$ & -4.82 & -0.14 & -13.51 \\
\hline $\begin{array}{l}\text { Estimated Fraction of } \\
\text { Existing Contracts that } \\
\text { are Short (\%) }\end{array}$ & 36.7 & 17.2 & 45.0 \\
\hline
\end{tabular}

1. Mean value for 16 quarters, $90: 1$ - 93:4.

2. Change in market value ( $\$$ billions) per 100 basis point increase in the interest rate. 
Table 7

Proportion of Swaps With Less than One Year Remaining, by Bank Group

(Percentage)

\begin{tabular}{|c|c|c|c|c|c|c|}
\hline Year & Quarter & $\begin{array}{c}\text { Portfolio } 1 \\
\text { Dealer Banks }\end{array}$ & $\begin{array}{l}\text { Portfolio } 2 \\
\text { Top 30, not } \\
\text { dealers }\end{array}$ & $\begin{array}{l}\text { Portfolio } 3 \\
\text { Total Assets }>\$ 5 \\
\text { bil. and not } 1 \text { or } 2\end{array}$ & $\begin{array}{c}\text { Portfolio } 4 \\
\text { Total assets } \\
\text { between } \$ 1-5 \text { bil. }\end{array}$ & $\begin{array}{c}\text { Porffolio } 5 \\
\text { Total Assets } \\
\text { between } \$ 500 \text { mil. } \\
-\$ 1 \text { bil. }\end{array}$ \\
\hline \multirow[t]{4}{*}{1990} & 1 & 31.6 & 26.0 & 31.5 & 38.9 & 23.0 \\
\hline & 2 & 32.0 & 26.2 & 32.5 & 41.9 & 25.9 \\
\hline & 3 & 31.2 & 26.3 & 34.9 & 45.0 & 25.6 \\
\hline & 4 & 32.4 & 26.4 & 34.9 & 46.8 & 26.4 \\
\hline \multirow[t]{4}{*}{1991} & 1 & 30.8 & 27.4 & 34.6 & 47.9 & 11.7 \\
\hline & 2 & 30.6 & 26.7 & 35.2 & 49.3 & 19.0 \\
\hline & 3 & 32.4 & 25.9 & 34.9 & 50.0 & 24.5 \\
\hline & 4 & 30.3 & 18.6 & 34.6 & 47.0 & 21.0 \\
\hline \multirow[t]{4}{*}{1992} & 1 & 30.0 & 26.8 & 33.0 & 41.9 & 20.6 \\
\hline & 2 & 30.2 & 27.8 & 34.6 & 45.3 & 18.8 \\
\hline & 3 & 29.4 & 27.3 & 33.3 & 41.8 & 19.6 \\
\hline & 4 & 30.5 & 27.9 & 32.5 & 42.8 & 16.6 \\
\hline \multirow[t]{4}{*}{1993} & 1 & 30.5 & 28.1 & 32.3 & 40.1 & 18,2 \\
\hline & 2 & 30.4 & 27.2 & 31.8 & 45.0 & 18.2 \\
\hline & 3 & 30.3 & 27.1 & 32.6 & 45.0 & 12.3 \\
\hline & 4 & 31.0 & 26.8 & 34.2 & 31.1 & 12.3 \\
\hline
\end{tabular}


Table 8

Market Value and Interest Sensitivities of Swap Positions by Bank Group

\begin{tabular}{|c|c|c|c|c|c|}
\hline & $\begin{array}{c}\text { Portfolio } 1 \\
\text { Dealer Banks }\end{array}$ & $\begin{array}{c}\text { Portfolio } 2 \\
\text { Top } 30, \begin{array}{c}\text { excluding dealer } \\
\text { banks }\end{array}\end{array}$ & $\begin{array}{c}\text { Portfolio } 3 \\
\text { Banks with total assets > } \\
\text { \$5 Billion, but not in top } 30\end{array}$ & $\begin{array}{l}\text { Portfolio } 4 \\
\text { Banks with total assets } \\
\text { in the range } \$ 1-5 \text { Billion }\end{array}$ & $\begin{array}{c}\text { Portfolio } 5 \\
\text { Banks with total assets } \\
\text { in the range } \$ 500 \\
\text { million-1 Billion }\end{array}$ \\
\hline $\begin{array}{c}\text { Calibrated Maturity } \\
\text { Structure }\end{array}$ & $\begin{array}{c}f^{0}=0.28 \\
f^{1}=f^{2}=f^{3}=f^{4}=0.18\end{array}$ & 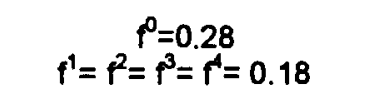 & $\begin{array}{c}f^{0}=0.38 \\
f^{1}=f^{2}=f^{3}=f^{4}=0.155\end{array}$ & $\begin{array}{c}f^{0}=0.78 \\
f^{1}=f^{2}=f^{3}=f^{4}=0.055\end{array}$ & $\begin{array}{c}f^{0}=0.16 \\
f^{1}=f^{2}=f^{3}=f^{4}=0.21\end{array}$ \\
\hline Estimated $1^{0}, 1^{1}, 1^{2}, 1^{3}, 1^{4}$ & $\begin{array}{c}1^{0}=1^{1}=1^{2}=1.0 \\
1^{3}=0.67 \\
1^{4}=0.0\end{array}$ & $\begin{array}{c}1^{0}=1^{1}=1^{2}=1.0 \\
1^{3}=0.63 \\
1^{4}=0.0\end{array}$ & $\begin{array}{l}I^{0}=I^{1}=1.0 \\
I^{2}=0.07 \\
1^{3}=0.0 \\
1^{4}=0.55\end{array}$ & $\begin{array}{c}P^{0}=1.0 \\
l^{1}=l^{2}=1^{3}=0.0 \\
l^{4}=0.55\end{array}$ & $\begin{array}{l}l^{0}=0.0 \\
l^{1}=0.05 \\
l^{2}=1^{3}=1.0 \\
1^{4}=0.44\end{array}$ \\
\hline $\begin{array}{c}\text { Swap Notional Value } \\
\text { (\$billions) }\end{array}$ & 1479.01 & 352.17 & 73.12 & 8.67 & 1.26 \\
\hline $\begin{array}{c}\text { Adjusted Replacement } \\
\text { Value }^{1} \text { (\$billions) }\end{array}$ & 21.85 & 5.71 & 1.35 & 0.21 & 0.01 \\
\hline $\begin{array}{c}\text { Estimated Market Value } \\
\text { (\$billions) }\end{array}$ & 6.71 & 1.83 & 0.43 & 0.04 & -0.01 \\
\hline $\begin{array}{c}\text { Estimated Interest } \\
\text { Sensitivity } \\
\text { (\$billions) }\end{array}$ & -8.98 & -2.86 & -1.25 & -0.11 & 0.03 \\
\hline $\begin{array}{c}\text { Standard Deviation of } \\
\text { Interest Sensitivity } \\
\text { (\$billions) }\end{array}$ & 5.62 & 8.65 & 5.23 & 0.83 & 0.10 \\
\hline $\begin{array}{c}\text { Percent Change in Equity } \\
\text { Value per } 100 \text { bp change } \\
\text { in int. rate (\%) }\end{array}$ & -22.74 & -4.09 & -2.94 & -0.79 & 1.64 \\
\hline $\begin{array}{c}\text { Estimated Fraction of } \\
\text { Existing Contracts that are } \\
\text { short (\%) }\end{array}$ & 33.92 & 33.66 & 37.20 & 60.26 & 33.80 \\
\hline
\end{tabular}

1. Mean value for 16 quarters, $90: 1-93: 4$.

2. Change in market value ( $\$$ bil.) per 100 basis point change in interest rate. 
Table 9

Maturity Gaps by Bank Group

\begin{tabular}{|c|c|c|c|c|c|c|c|c|c|c|}
\hline & \multicolumn{2}{|c|}{ Portfolio 1} & \multicolumn{2}{|c|}{ Portfolio 2} & \multicolumn{2}{|c|}{ Portfolio 3} & \multicolumn{2}{|c|}{ Portfolio 4} & \multicolumn{2}{|c|}{ Portfolio 5} \\
\hline Year & MATGAP & MATGAP* & MATGAP & MATGAP* & MATGAP & MATGAP* & MATGAP & MATGAP* & MATGAP & MATGAP * \\
\hline 1990 & 23.4 & 28.7 & -8.7 & 1.2 & -7.7 & 1.9 & -12.7 & -1.8 & -15.7 & -3.9 \\
\hline 1991 & 21.6 & 27.0 & -11.7 & -1.2 & -12.0 & -1.6 & -17.2 & -5.6 & -19.5 & -6.9 \\
\hline 1992 & 19.7 & 25.9 & -13.2 & -1.2 & -14.5 & -2.3 & -19.6 & -6.4 & -22.7 & -8.4 \\
\hline 1993 & 20.4 & 26.5 & -9.9 & 2.4 & -12.4 & 0.1 & -18.9 & -5.3 & -22.5 & -7.8 \\
\hline Mean & 21.3 & 27.0 & -10.9 & 0.31 & -11.6 & -0.5 & -17.1 & -4.7 & -20.1 & -6.7 \\
\hline
\end{tabular}

MATGAP is the one year maturity gap assuming that all assets and liabilities have effective maturities equal to their stated maturities. MATGAP* assumes that 40 percent of demand deposits and 40 percent of NOW accounts do not reprice within one year.

Source: Call Reports of Income and Condition 
Table 10

Sensitivity of Net Income to Swap Positions

\begin{tabular}{|c|c|c|c|c|c|c|c|c|}
\hline & \multicolumn{2}{|c|}{ (1) } & \multicolumn{2}{|c|}{ (2) } & \multicolumn{2}{|c|}{ (3) } & \multicolumn{2}{|c|}{ (4) } \\
\hline $\begin{array}{c}\text { Independent } \\
\text { Variable }\end{array}$ & $\begin{array}{l}\text { Estimated } \\
\text { Coefficient }\end{array}$ & $\begin{array}{l}\text { Standand } \\
\text { Error }\end{array}$ & $\begin{array}{l}\text { Estimated } \\
\text { Coefficient }\end{array}$ & $\begin{array}{l}\text { Standard } \\
\text { Error }\end{array}$ & $\begin{array}{l}\text { Estimated } \\
\text { Coefficient }\end{array}$ & $\begin{array}{l}\text { Standard } \\
\text { Error }\end{array}$ & $\begin{array}{l}\text { Estimated } \\
\text { Coefficient }\end{array}$ & $\begin{array}{c}\text { Standard } \\
\text { Error }\end{array}$ \\
\hline Intercept & 1.02 & $0.036^{*}$ & 1.24 & $0.039^{\star}$ & & & & \\
\hline$\Delta R$ & 0.33 & $0.065^{*}$ & 0.24 & $0.053^{*}$ & 0.33 & $0.045^{*}$ & 0.43 & $0.073^{*}$ \\
\hline Charge-offs & & & -0.35 & $0.041^{*}$ & -0.23 & $0.043^{*}$ & -0.18 & $0.051^{*}$ \\
\hline$\Delta M V \Delta R 1^{*} \Delta R$ & & & & & 0.09 & $0.039^{* t *}$ & 0.10 & $0.033^{* *}$ \\
\hline$\Delta M V \Delta R 2^{*} \Delta R$ & & & & & 0.47 & $0.20^{\text {\#\# }}$ & 0.53 & $0.172^{* \pm}$ \\
\hline$\Delta M V \Delta R 3^{*} \Delta R$ & & & & & 0.50 & 0.358 & & \\
\hline$\Delta M V \Delta R 4^{*} \Delta R$ & & & & & 1.62 & 1.332 & & \\
\hline$\Delta M V \Delta R 5^{*} \Delta R$ & & & & & -0.96 & 0.726 & & \\
\hline Portfolio 1 & & & & & 1.17 & $0.076^{\star}$ & 1.14 & $0.079^{*}$ \\
\hline Portfolio 2 & & & & & 1.14 & $0.057^{\star}$ & 1.14 & $0.054^{*}$ \\
\hline Portfolio 3 & & & & & 1.03 & $0.061^{*}$ & & \\
\hline Portfolio 4 & & & & & 1.08 & $0.057^{*}$ & & \\
\hline Portfolio 5 & & & & & 1.00 & $0.064^{*}$ & & \\
\hline Portfolio 6 & & & & & 1.58 & $0.050^{*}$ & & \\
\hline Portfolio 7 & & & & & 1.15 & $0.055^{\star}$ & & \\
\hline Portfolio 8 & & & & & 1.23 & $0.052^{\star}$ & & \\
\hline & & & & & & & & \\
\hline Prob>F & 0.0001 & & 0.0001 & & 0.0001 & & 0.0001 & \\
\hline Adj. $R^{2}$ & 0.1685 & & 0.4783 & & 0.6907 & & 0.6758 & \\
\hline
\end{tabular}

Dependent variable is net income divided by total assets. $\Delta R$ is the change in the 3-month T-bill rate; $\Delta M V \Delta R i^{\star} \Delta R$ is the interest sensitivity of portfolio i's swap portfolio times the change in the 3-month T-bill rate; Portfolio $i$ is a dummy variable for portfolio $i$. * indicates significant at the .01 level; ** indicates significance at the .05 level. 